\title{
SYTUACJA EKONOMICZNA KLASZTORU PAULINÓW W LEŚNEJ (NA TLE GOSPODARKI INNYCH PLACÓWEK PAULIŃSKICH DZIALAJĄCYCH WE WSCHODNICH WOJEWÓDZTWACH RZECZPOSPOLITEJ)
}

\section{Streszczenie}

Jedną z najważniejszych placówek polskiej prowincji paulinów w XVIII-XIX wieku był klasztor w Leśnej na Podlasiu. Został on ufundowany w 1726 r. przezwłaścicielawsiWładysławaJanaMichałowskiego.PoIIIrozbiorzew1795r. Leśna znalazła się w Galicji Zachodniej, od 1809 r. miejscowość leżała w Księstwie Warszawskim, w latach 1815-1918 w Królestwie Polskim, znajdującym się pod władzą carów Rosji. Klasztor został skasowany w 1864 r.

Klasztor otrzymał bardzo duże uposażenie. W jego posiadaniu do $1795 \mathrm{r}$. znajdowało się 16 wsi, jednak w wyniku III rozbioru paulini utracili na rzecz skarbu rosyjskiego większość swoich dóbr. Do końca istnienia posiadał jedynie 4 wsie. Areał ziemi klasztornej w XVIII wieku wynosił 4907 mórg, a po 1795 r. jedynie 842,50 morgi (o 82,83\% mniej niż wcześniej). Tak duże uposażenie, powodowało, że klasztor leśniański był drugim najlepiej zabezpieczonym po Jasnej Górze konwentem w polskiej prowincji paulinów.

Paulini w Leśnej w największych ilościach siali żyto, pszenicę, jęczmień, owies, uprawiali także tatarkę, groch, proso, grykę i len. Na poziom produkcji roślinnej duży wpływ miały działania zbrojne, które toczyły się w rejonie klasztoru. Występowało wówczas zagrożenie życia i zdrowia oraz liczne grabieże dokonywane przez maszerujące armie, np. w latach 1812-1813 i 1831. Najwięcej plonów wydatkowano na zasiewy i spożycie w klasztorze, natomiast w XIX wieku część zbiorów sprzedawano na rynku lokalnym. Wydaje się, że w XIX wieku nastąpiła również poprawa kultury rolnej, co przyniosło wzrost wydajności. W dobrach klasztornych hodowano woły i konie jako siłę roboczą oraz bydło mleczne, owce, świnie, drób i pszczoły. Hodowla była przeznaczona przede wszystkim na zaspokojenie własnych potrzeb.

\footnotetext{
* Jacek Szpak - dr hab. historii; adiunkt, Instytut Historii, Uniwersytet Śląski w Katowicach e-mail: starling@onet.eu

https://orcid.org/0000-0003-3464-9214
} 
Dużą rolę w działalności ekonomicznej klasztoru odgrywała gospodarka pozarolnicza, czyli młynarstwo, propinacja oraz produkcja cegieł. Na podstawie zachowanych, niekompletnych materiałów archiwalnych ustalono, że największe dochody uzyskiwano z czynszów dzierżawnych, z odsetek wyderkafowych oraz z depozytów bankowych i spłaty listów zastawnych. Najwięcej wydawano na prace budowlane i remontowe, podatki, pensje dla czeladzi oraz na utrzymanie zakonników. Sytuacja finansowa klasztoru była niestabilna, jednak klasztor w Leśnej utrzymywał się samodzielnie, korzystając z pomocy władz prowincji tylko raz w latach 30 . XIX wieku.

Słowa kluczowe: paulini; zakon męski; Leśniów; Włodawa; gospodarka klasztorna; Kościół katolicki

\section{Wstęp}

Kościół katolicki w polskich dziejach odgrywał istotną rolę zarówno w dziedzinie kultury, nauki, polityki, jak i w gospodarce. Wśród historyków, którzy próbowali opisać niektóre problemy gospodarcze, należy wymienić m.in.: Ewę M. Ziółek, Wojciecha Kędera, Dariusza Złotkowskiego, Zygmunta Zaborskiego i Jacka Szpaka. W pracach tych autorów poruszono jednak tylko wybrane problemy ${ }^{1}$. Niewiele publikacji naukowych dotyczy gospodarki zakonów polskich w okresie nowożytnym (XVI-XIX wiek)². Istnieje zatem potrzeba podjęcia badań

${ }^{1}$ E.M. Ziółek, Między tronem a oltarzem. Kościót i państwo w Księstwie Warszawskim, Lublin 2012; W. Kęder, Jasna Góra wobec przemian politycznych w Rzeczypospolitej w latach 1661-1813, „Studia Claromontana”, 13 (1993) s. 5-206; D. Złotkowski, Udziat zakonu ojców paulinów w życiu społeczno-politycznym Rzeczypospolitej w XVIII w., Częstochowa 1994; Z. Zaborski, Parafia Wiewiec. Zarys dziejów, Częstochowa 1999; Z. Zaborski, Rezydencja paulinów w Wiewcu, „Studia Claromontana", 6 (1985) s. 160-193; J. Szpak, Ciężary wojskowe z dóbr starostwa brzeźnickiego w latach 1651-1793, w: Pecunia nervus belli. Z dziejów dyplomacji i stosunków międzynarodowych w XVI-XVIII wieku, red. M. Markiewicz, R. Skowron, F. Wolański, Katowice 2016; J. Szpak, Finanse starostwa kłobuckiego 1659-1789, „Magazyn Numizmatyczny”, (2014) nr 40; J. Szpak, Dzieje klasztoru i parafii w Leśniowie, cz. 3: Parafia i sanktuarium Matki Bożej w Leśniowie, poddani klasztoru i parafii, „Studia Claromontana”, 20 (2002) s. 405-636; J. Szpak, Gospodarka feudal$n a w$ dobrach klasztoru paulinów w Leśniowie w XVIII i XIX wieku. Wybrane problemy, „Zeszyty Myszkowskie", (2017) nr 4, s. 9-28.

${ }^{2}$ W 2013 r. w tomie pt. Klasztor w gospodarce średniowiecznej i nowożytnej, red. M. Derwich, Wrocław 2013, opublikowano kilkanaście artykułów na temat gospodarki klasztornej na ziemiach Rzeczypospolitej, m.in.: S. Kościelak, Majątek ruchomy i nieruchomy klasztoru brygidek w Gdańsku u progu kasat oraz jego losy po kasacie w 1835 r. Wstęne ustalenia; W. Rosowski, Sytuacja gospodarcza klasztoru bernardynów w Janowie na Podolu u progu kasat oraz losy jego majatku po kasacie w 1832 r.; H. Rusińska-Giertych, Dochody klasztorów wynikające z działalności typograficznej na przykładzie drukarni franciszkanów we Lwowie (1770-1776); A. Szylar, , Sprawa o tym, jak benedyktynki gospodarstwo prowadzity...". Organizacja i funkcjonowanie gospodarki opactwa benedyktynek w Sandomierzu w XVII i XVIII w.; H. Święch, Źródta utrzymania klasztoru bernardynek przy kościele pw. św. Agnieszki na Stradomiu w Krakowie oraz stan ich dochodów u progu kasaty klasztoru w 1788 r. i po przeniesieniu konwentu do klasztoru bernardynek przy kościele pw. św. Józefa; T.M. Trajdos, Dobra i dochody klasztorne augustianów w Brześciu Litewskim w świetle 
nad ogółem zagadnień związanych z gospodarczymi podstawami funkcjonowania np. klasztorów paulińskich w Polsce.

Artykuł powstał na podstawie dokumentacji przechowywanej w Archiwum Zakonu Paulinów na Jasnej Górze w Częstochowie (dalej: AJG) oraz literaturze przedmiotu. Ponadto wykorzystano materiały z innych archiwów krajowych oraz z Centralnego Archiwum Historycznego Ukrainy we Lwowie (dalej: CDIAUL). Do opracowania zagadnień zastosowano metody analityczną oraz statystyczną. Starano się również porównać sytuację ekonomiczną klasztorów w Leśnej, Włodawie, Wilnie, Norzyńsku, Horoszkach i Niżniowie.

Dobra klasztoru w Leśnej znajdowały się na obszarze województw brzesko-litewskiego, podlaskiego i ruskiego, a placówki włodawskiej leżały w województwie brzesko-litewskim. Natomiast majątki należące do rezydencji w Wilnie znajdowały się w województwie wileńskim i witebskim, wsie należące do rezydencji w Norzyńsku i Horoszkach na terytorium województwa kijowskiego, a klasztor w Niżniowie leżał w województwie ruskim³ ${ }^{3}$

\section{Zarys dziejów klasztoru w Leśnej}

Jedną z najważniejszych placówek polskiej prowincji paulinów był klasztor w Leśnej. Była to wieś, która powstała najprawdopodobniej w XIII-XIV wieku jako Kamionka. Na początku XVII wieku przyjęła nazwę Leśna. Na przełomie XV-XVI wieku należała do dóbr Bukowice, których właścicielami byli Połubińscy, Dembińscy, Koniecpolscy, a w 1625 r. dobra kupił Mikołaj Firlej. Po 1650 r. właścicielem wsi był Adam Franciszek Warszycki. Po jego śmierci dobra odziedziczyli ok. 1676 r. Michałowscy. W drugiej połowie XVII wieku właścicielem Leśnej był Paweł Franciszek Michałowski skarbnik orszański. W 1688 r. ufundował on parafię, którą uposażył, przekazując wieś Leśna. Fundator zastrzegł jednak prawo prezenty dla swego rodu, a w razie jej wygaśnięcia prawo miało przejść na biskupów łuckich. Nowa parafia obejmowała wsie Leśną i Klukowszczyznę. Po III rozbiorze w 1795 r. Leśna znalazła się w Galicji Zachodniej, od 1809 r. miej-

archiwaliów konwentualnych (do końca XVII w.), w: Klasztor w gospodarce średniowiecznej i nowożytnej, red. M. Derwich, Wrocław 2013.

${ }^{3}$ Archiwum Zakonu Paulinów na Jasnej Górze w Częstochowie (dalej: AJG) 974, s. 2, 81; AJG 1620, s. 1-3; AJG 537, Actorum Provinciae Poloniae (dalej: APP), t. 7, s. 347; AJG 1557, s. 1-2; AJG 973, s. 1-10; AJG 1611, s. 11; AJG 1585, s. 9, 11, 33; AJG 1658, s. 49-52; Księga 3. Z uzupetnieniami obejmujace lata od 1727 do 1786. Ks. 3. Autor: o. Marcin Streska OSPEE, w: Roczniki zakonu św. Pawła Pierwszego Pustelnika, t. 1, red. L. Chałupka, Częstochowa-Jasna Góra 2008, s. 905, 120, 209; J. Zbudniewek, Paulini wczoraj i dzisiaj, „Studia Claromontana”, 25 (2007) s. 220, 242-243; J. Zbudniewek, Katalog domów i rezydencji polskiej prowincji paulinów. „Nasza Przeszłość”, 31 (1969) s. 202, 212-213; Urzędnicy województw kijowskiego i czernihowskiego XV-XVIII wieku. Spisy, oprac. E. Janas, W. Kłaczewski, Kórnik 2002, s. 49 (poz. 241); Urzędnicy województwa sandomierskiego XVI-XVIII wieku. Spisy, oprac. K. Chłapowski, A. Falniowska-Grabowska, red. A. Gąsiorowski, Kórnik 1993, s. 66 (poz. 406); J. Szpak, Sytuacja ekonomiczna klasztoru paulinów we Włodawie w latach 1698-1864, „Studia Claromontana”, 33 (2017/2018) s. 80-81. 
scowość leżała w Księstwie Warszawskim, a w latach 1815-1918 w Królestwie Polskim, znajdującym się pod władzą carów Rosji ${ }^{4}$.

W 1726 r. potomek P.F. Michałowskiego, Władysław Jan sprowadził do Leśnej paulinów. Przekazał również zakonowi prawo patronatu świątyni leśniańskiej $^{5}$. Kapituła łucka potwierdziła nadanie W.J. Michałowskiego w 1727 r. W Leśnej paulini prowadzili działalność duszpasterską w parafii. Utrzymywali oni również dla unitów księdza, który odprawiał nabożeństwa w obrządku wschodnim. W latach 1831-1845 w Leśnej funkcjonowało studium zakonne dla kleryków. Konwent skasowały władze carskie w 1864 r. ${ }^{6}$

\section{Dobra ziemskie}

P.F. Michałowski w 1726 r. zapisał paulinom wsie: Leśna, Bordziłówka i Klukowszczyzna, a książę Franciszek Michał Szujski w 1728 r. Malowę Górę, Berezówkę, Starzynę (Mardarowicze), Buczembal (Świszczowa) i Samowicze. Wszystkie posiadłości znajdowały się na terytorium województwa brzesko-litewskiego. O dobra Malowa Góra toczył się jednak przez wiele lat spór z dziedzicami księcia F.M. Szujskiego, dlatego też zakon przejął tylko Buczembal, a pozostałe wsie trafiły do spadkobierców F.M. Szujskiego?

W 1729 r. klasztor w Leśnej otrzymał także wieś Bukowce Stare, w 1732 r. dobra Droblin leżące w województwie podlaskim i ziemi mielnickiej. W latach 1740-1753 r. klasztor posiadał folwarki w Leśnej, Droblinie, Klukowie i Buczembalu. Dopiero w 1754 r. paulini zamienili z Jerzym Flemingiem wsie Malowa Góra i Samowicze na Chrypsk, Chrypską Wólkę i Polemiec leżące w województwie ruskim. Dobra Buczembal, Chrypsk, Chrypska Wólka, Polemiec, Konstantynów, Klawań i Żebranie na mocy konwencji petersburskiej z 1797 r. przejęła Rosja ${ }^{8}$. Po 1795 r. własnością klasztoru pozostały jedynie wsie Leśna, Klukowszczyzna, Bordziłówka i Droblin'.

Do schyłku Rzeczpospolitej klasztor w Leśnej miał 16 wsi (Leśna, Bordziłówka, Klukowszczyzna, Berezówka, Starzyna vel Mardarowicze, Buczembal, Bukowce Stare, Droblin, Chrypsk, Chrypska Wólka, Polemiec, Bukowce Stare, Droblin,

${ }^{4}$ J. Szpak, Klasztor paulinów w Leśnej 1726-1864. Poczatki, struktura organizacyjna, życie codzienne, podstawy ekonomiczne, ,Rocznik Bialskopodlaski”, 24 (2016) s. 71.

${ }^{5}$ AJG 1624, s. 1-3.

${ }^{6}$ AJG 1545, s. 71-72; AJG 1546, s. 3-5; AJG 1548, s. 1-7; Zbudniewek, Katalog domów i rezydencji, s. 191; Zbudniewek, Paulini wczoraj i dzisiaj, s. 196; J. Maraśkiewicz, Leśna Podlaska. Architektura kościoła, Biała Podlaska 1983, s. 11-12.

${ }^{7}$ Szpak, Sytuacja ekonomiczna klasztoru, s. 80-81.

${ }^{8}$ AJG 1545, s. 15-18, 67-70; Maraśkiewicz, Leśna Podlaska. Architektura, s. 12.

${ }_{9}^{9}$ AJG 495, s. 169-170, 227-229; AJG 595, s. 147-151, 155; AJG 1545, s. 43-44; AJG 1548, s. 1-7, 81-83, 147; AJG 1622, s. 73-74; AJG 1623, s. 54; Księga 3. Z uzupetnieniami obejmujace lata od 1727 do 1786. Autor: o. Marcin Streska OSPEE, w: Roczniki zakonu św. Pawła Pierwszego Pustelnika, t. 1, red. L. Chałupka, Częstochowa-Jasna Góra 2008, s. 210; Zbudniewek, Katalog domów i rezydencji, s. 191; Zbudniewek, Paulini wczoraj i dzisiaj, s. 196; K. Szafraniec, Decus-Podlachiae. Ozdoba Podlasia. Sanktuarium Matki Boskiej Leśniańskiej w trzechsetlecie istnienia (1683-1983), „Collectanea Teologica”, 51 (1981) nr 3, s. 26. 
Konstantynów, Klawań i Żebranie). W wyniku III rozbioru paulini utracili na rzecz skarbu rosyjskiego większość swoich dóbr. Do końca istnienia klasztor posiadał jedynie cztery wsie (Leśna, Klukowszczyzna, Bordziłówka, Droblin) ${ }^{10}$.

Warto również porównać liczbę jednostek osadniczych oraz areał całkowity $\mathrm{w}$ dobrach poszczególnych klasztorów paulińskich w Polsce. Najwięcej miast, wsi i osad oraz największy areał posiadał klasztor jasnogórski, ale placówka w Leśnej znalazł się w tym zestawieniu na drugim miejscu. Kolejne klasztory nie miały już tak rozległych dóbr, zatem pod względem ekonomicznym konwent leśniański odgrywał bardzo ważną rolę w polskiej prowincji.

${ }^{10}$ Szpak, Klasztor paulinów w Leśnej, s. 81-82. 


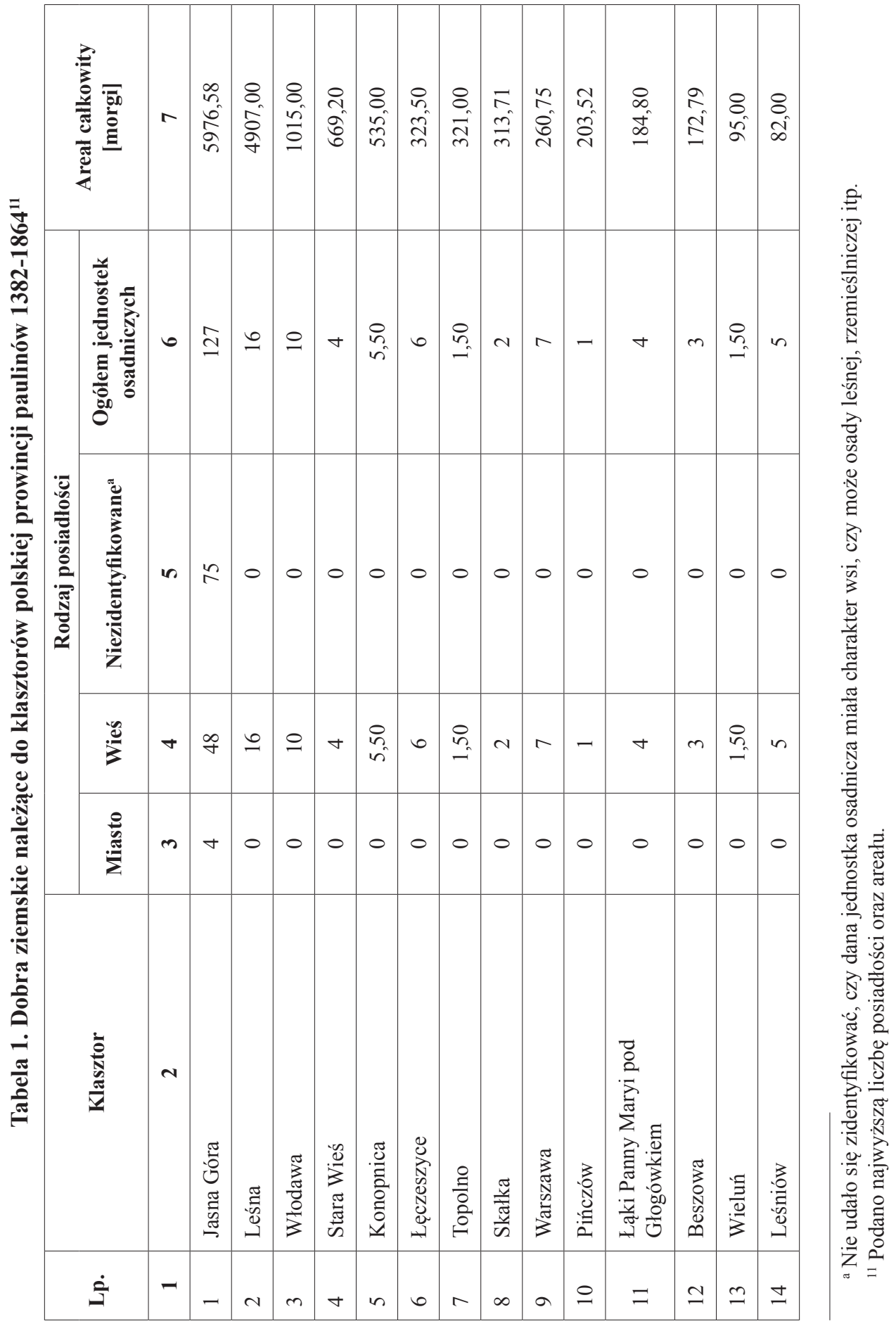




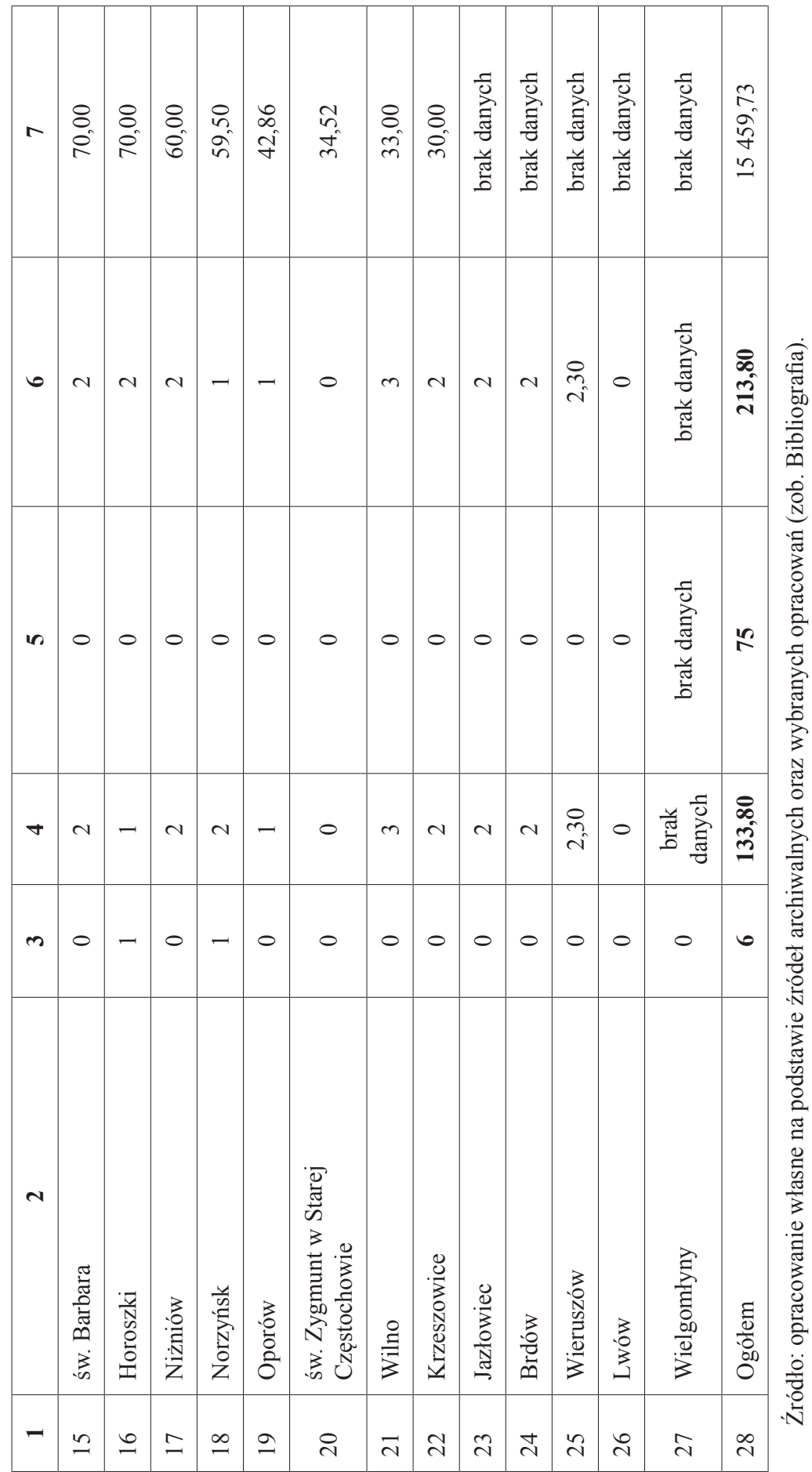


Można również dokonać porównania areału całkowitego, jaki posiadał klasztor leśniański z konwentami cystersów. Jak widać, spośród siedmiu z nich Leśna zajęła czwarte miejsce. Gospodarstwo leśniańskie zostało przewyższone areałem przez opactwa w Henrykowie, Trzebnicy i Krzeszowie. Natomiast opactwa w Rudach, Lubiążu i Jemielnicy miały mniejszą powierzchnię gospodarstwa.

Tabela 2. Powierzchnia dóbr klasztoru paulinów w Leśnej oraz klasztorów cysterskich funkcjonujących na ziemiach polskich w XVII-XIX wieku

\begin{tabular}{|l|c|}
\hline Klasztor & Największy areal całkowity [morgi] \\
\hline Opactwo cystersów w Henrykowie na Śląsku & $57585,90^{\mathrm{b}}$ \\
\hline Opactwo cystersów w Trzebnicy na Śląsku & $47220,00^{\mathrm{c}}$ \\
\hline Opactwo cystersów w Krzeszowie na Śląsku & $5357,10^{\mathrm{d}}$ \\
\hline Klasztor w Leśnej & 4907,00 \\
\hline Opactwo cystersów w Rudach na Śląsku & $3162,00^{\mathrm{e}}$ \\
\hline Opactwo cystersów w Lubiążu na Śląsku & $2166,06^{\mathrm{f}}$ \\
\hline Opactwo cystersów w Jemielnicy na Śląsku & $1071,00^{\mathrm{g}}$ \\
\hline
\end{tabular}

Źródło: zob. tabela nr 1; wybrane opracowania (zob. Bibliografia).

\section{Gospodarka roślinna}

Areał ziemi uprawnej w dobrach klasztoru leśniańskiego wahał się między 2456,68 w XVIII wieku a 46,89 morgi w $1815 \mathrm{r}^{12}{ }^{12}$ Tutaj należy podkreślić, że tak ogromna utrata areału ziemi uprawnej wynikała z rozbiorów Rzeczpospolitej. Wystarczy wspomnieć, że w pierwszej połowie XVIII wieku areał całkowity wy-

b Tylko folwarki klasztoru bez filii, kaplic i kapelanii.

c Tylko folwarki klasztoru bez filii, kaplic i kapelanii.

${ }^{\mathrm{d}}$ Wszystkie folwarki, również te znajdujące się w filiach i kapelaniach.

e Tylko folwarki klasztoru bez filii, kaplic i kapelanii.

${ }^{\mathrm{f}}$ Tylko folwarki klasztoru bez filii, kaplic i kapelanii.

${ }^{g}$ Wszystkie folwarki, również te znajdujące się w filiach i kapelaniach.

${ }^{12}$ Za Andrzejem Wyczańskim przyjęto, że wysiewy czterech podstawowych zbóż wynosiły: żyto $-2,5$ korca na mórg, pszenica $-2,3 \mathrm{k}$. na mórg, jęczmień $-2,6 \mathrm{k}$. na mórg i owies $-3,3 \mathrm{k}$. na mórg. Materiał archiwalny pozwala również na określenia odsetka wysiewów pozostałych roślin, nie jest to jednak jednoznaczne z odsetkiem zasianego areału. Dlatego też za J. Muszyńską uznano, że wysiewy innych roślin zajmowały średnio $10 \%$ zasianego areału zbożami głównymi, a nieużytki, pastwiska i łąki wynosiły 50\% zasiewów. Zob. A. Dunin-Wąsowicz, Pomiary gruntu w Koronie w XVI-XVIII wieku, Warszawa 1994, s. 184-185; J. Muszyńska, Gospodarka dworska w dobrach biskupów krakowskich w połowie XVII wieku, Kielce 2012, s. 40-41. 
nosił 4907 mórg. Jednak Rosjanie przejęli 4064,50 morgi, czyli aż 82,83\% całej ziemi klasztornej w Leśnej ${ }^{13}$.

Jak widać, zawirowania polityczne miały ogromny wpływ na kondycję gospodarczą klasztoru w Leśnej, ale również innych placówek paulińskich. Należy bowiem wspomnieć, że konwent we Włodawie do 1795 r. był właścicielem majątku o powierzchni 1015 mórg, a po III rozbiorze, kiedy to Rosjanie zajęli znaczną część dóbr włodawskich, paulinom pozostawiono 488 mórg. Zatem strata wyniosła 527 mórg, czyli 51,92\% areału ${ }^{14}$. Trzeba również wspomnieć, że klasztor w Niżniowie został skasowany 2 lutego 1786 r. na mocy dekretu cesarza Józefa II $^{15}$. Utrata dóbr ziemskich i kasata klasztorów zdecydowanie osłabiała potencjał ekonomiczny $\mathrm{i}$ instytucjonalny Kościoła polskiego.

Najmniejszy areał w Leśnej uprawiano w 1815 r., co było związane ze zniszczeniami wojennymi. Niewielki obszar ziemi uprawnej w latach 1815-1839 wynikał również z faktu, że w dzierżawę oddawano części dóbr klasztornych. Stąd też w inwentarzach klasztornych występowały tylko te dobra, które były zarządzane bezpośrednio przez przeora. W 1855 r. widać znaczny wzrost areału, co było zapewne związane $\mathrm{z}$ rezygnacją $\mathrm{z}$ wydzierżawiania dóbr - $\mathrm{w}$ badanym okresie wynosił średnio 842,40 morgi $^{16}$.

Z kolei we Włodawie w latach 1745-1788 zasiewano od 677,05 do 54,45 morgi, a średnia wynosiła 227,40 morgi. Podobnie jak w przypadku dóbr w Leśnej i w majątkach włodawskich po 1795 r. widać znaczny spadek zasiewanego areału, najmniejszy uprawiano w 1863 r., bo zaledwie 54,45 morgi, co wynikało z możliwości obsiania gruntów oraz potrzeb gospodarczych ${ }^{17}$. W innych placówkach paulińskich działających na wschodnich obszarach Rzeczpospolitej zasiewano stosunkowo niewiele ziemi. W majątkach rezydencji w Wilnie uprawiano od 17,79 do 10,95 morgi, w rezydencji w Krzeszowicach maksymalnie 10 mórg, w klasztorze w Niżniowie zagospodarowywano od 40,65 do 2,19 morgi, w dobrach rezydencji w Horoszkach od 47,10 do 4,56 morgi, a w rezydencji w Norzyńsku od 39,58 do 8,40 morgi $^{18}$. Jak widać, w Leśnej uprawiano największy areał w porównaniu z innymi placówkami paulińskimi działającymi za wschodzie Rzeczpospolitej.

${ }^{13}$ AJG 595, s. 147-152, 169, 173; AJG 1622, s. 277, 342-343, 353; AJG 1623, s. 54; AJG 1547, s. $177-182$.

${ }^{14}$ AJG 596, s. 27-47, 221-223; AJG 1661, s. 231-232, 328.

${ }^{15}$ AJG 1557, s. 1-2; Zbudniewek, Katalog domów i rezydencji, s. 212-213; Zbudniewek, Paulini wczoraj i dzisiaj, s. 242-243; Księga 3, s. 120

${ }^{16}$ AJG 596, s. 27-47, 221-223; AJG 1661, s. 231-232, 328.

${ }^{17}$ AJG 595, s. 147-152, 169, 173; AJG 1547, s. 177-182; AJG 1622, s. 277, 342-343, 353; AJG 1623, s. 54.

${ }^{18}$ AJG 1658, s. 49-52; AJG 1585, s. 33; AJG 1532, s. 27; AJG 1531, s. 11-20; AJG 1620, s. 48, 51. 
Tabela 3. Areał uprawny w dobrach klasztoru w Leśnej w latach 1747-1855

\begin{tabular}{|l|c|c|}
\hline \multirow{2}{*}{ Folwark } & Rok & Areal zasiewów [morgi] \\
\hline $\begin{array}{l}\text { Leśna, Buczembal, } \\
\text { Klukowszczyzna, Droblin }\end{array}$ & 1747 & 2456,68 \\
\hline \multirow{3}{*}{ Leśna, Klukowszczyzna } & 1815 & 46,89 \\
\cline { 2 - 3 } & 1824 & 57,99 \\
\cline { 2 - 3 } & 1828 & 54,04 \\
\cline { 2 - 3 } & 1838 & 54,24 \\
\hline $\begin{array}{l}\text { Leśna, Klukowszczyzna, } \\
\text { Bordziłówka }\end{array}$ & 1839 & 56,87 \\
\hline
\end{tabular}

Obliczenia własne na podstawie: AJG 595, s. 147-152, 169, 173; AJG 1622, s. 277, 342-343, 353; AJG 1623, s. 54; AJG 1547, s. 117-182.

W tabieli nr 4 przedstawiono poziom wysiewów w dobrach klasztornych w latach 1747-1839. Zasiewano przede wszystkim cztery podstawowe zboża (pszenica, żyto, jęczmień, owies) oraz tatarkę (gryka), groch, rzepak, len i proso. Należy zauważyć, że w 1839 r. struktura wysiewów gwałtownie zubożała, ponieważ zasiewano wówczas tylko żyto i pszenicę. Najwięcej było żyta (47,78-84,31\%) i jęczmienia (2,17-5,38\%). Wysiewy pszenicy w 1815 r. były niewielkie, ale w następnych latach wzrastały, co wiązało się z odbudową gospodarczą po zniszczeniach wojennych. Sumując wszystkie wysiewy, największe były w 1747 r., a najmniejsze w 1815 r. zaznaczyła się stabilizacja w ilości zasiewów, ale w 1839 r. ilość wysianego ziarna spadła. Uprawy dodatkowe (tatarka, groch, proso, rzepak, len) stanowiły od 4,70 do 1,53\% wszystkich wysiewów. W latach 50. XIX wieku obok wymienionych dotychczas upraw pojawił się również bób ${ }^{19}$.

Z kolei w dobrach klasztoru we Włodawie w latach 1745-1788 najwięcej wysiewano żyta ozimego i jarego oraz owsa i jęczmienia, a niewiele pszenicy. Natomiast w latach 1815-1863 dominowały wysiewy żyta ozimego, owsa i jęczmienia, a w 1815 r. pojawiła się uprawa ziemniaka, która do końca funkcjonowania klasztoru odgrywała ważną rolę ${ }^{20}$.

${ }^{19}$ AJG 1547, s. 161-173, 177-182; AJG 1622, s. 353; AJG 1623, s. 54; AJG 595, s. 147-152, $169,173$.

${ }^{20}$ Szpak, Sytuacja ekonomiczna klasztoru, s. 696-698. 
Tabela 4. Struktura wysiewów w dobrach klasztoru w Leśnej w latach 1747-1839

\begin{tabular}{|c|c|c|}
\hline Uprawa & Wysiewy [korce] & Odsetek [\%] \\
\hline 1 & 2 & 3 \\
\hline \multicolumn{3}{|c|}{1747} \\
\hline żyto & 605,25 & 66,99 \\
\hline pszenica & 13,75 & 1,51 \\
\hline jęczmień & 161,00 & 17,82 \\
\hline owies & 81,00 & 8,97 \\
\hline tatarka & 15,00 & 1,66 \\
\hline groch & 12,25 & 1,36 \\
\hline proso & 15,25 & 1,69 \\
\hline ogółem & 903,50 & 100,00 \\
\hline \multicolumn{3}{|c|}{1815} \\
\hline żyto & 56,50 & 47,78 \\
\hline pszenica & 1,00 & 0,85 \\
\hline jęczmień & 30,00 & 25,37 \\
\hline owies & 27,00 & 22,83 \\
\hline groch & 1,50 & 1,27 \\
\hline gryka & 2,00 & 1,69 \\
\hline proso, rzepak, len & 0,25 & 0,21 \\
\hline ogólem & 118,25 & 100,00 \\
\hline \multicolumn{3}{|c|}{1824} \\
\hline żyto & 100,50 & 72,56 \\
\hline pszenica & 15,00 & 10,83 \\
\hline jęczmień & 3,00 & 2,17 \\
\hline owies & 16,00 & 11,55 \\
\hline gryka & 2,00 & 1,44 \\
\hline proso & 2,00 & 1,44 \\
\hline ogółem & 138,50 & 99,99 \\
\hline \multicolumn{3}{|c|}{1828} \\
\hline żyto & 81,00 & 62,07 \\
\hline pszenica & 12,00 & 9,19 \\
\hline jęczmień & 11,50 & 8,81 \\
\hline owies & 24,00 & 18,39 \\
\hline groch & 1,00 & 0,77 \\
\hline gryka & 1,00 & 0,77 \\
\hline ogólem & 130,50 & 100,00 \\
\hline
\end{tabular}




\begin{tabular}{|l|c|c|}
\hline \multicolumn{2}{|c|}{$\mathbf{1}$} & $\mathbf{1}$ \\
\hline \multicolumn{2}{|c|}{$\mathbf{1 8 3 0}$} \\
\hline żyto & 81,00 & 61,95 \\
\hline pszenica & 12,00 & 9,18 \\
\hline jęczmień & 11,50 & 8,79 \\
\hline owies & 24,00 & 18,36 \\
\hline ogółem & 2,25 & 1,72 \\
\hline \multicolumn{3}{|c|}{$\mathbf{1 3 0 , 7 5}$} \\
\hline żyto & $\mathbf{1 8 3 9}$ & $\mathbf{1 0 0 , 0 0}$ \\
\hline pszenica & 107,50 & 84,31 \\
\hline ogółem & 20,00 & 15,69 \\
\hline
\end{tabular}

Obliczenia własne na podstawie: AJG 595, s. 147-152, 169, 173; AJG 1622, s. 277, 342-343, 353; AJG 1623, s. 54; AJG 1547, s. 117-182.

W rezydencji wileńskiej w latach 1732-1733 najwięcej wysiewano żyta, owsa i orkiszu. Ponadto uprawiano pszenicę, groch, jęczmień i tatarkę ${ }^{21}$. Z kolei w Horoszkach w latach 1717-1723 największy areał zasiewów zajmowały żyto ozime i jare, owies oraz hreczka (gryka). Obok wymienionych roślin uprawiano jeszcze pszenicę jarą i ozimą, jęczmień, proso i groch ${ }^{22}$. W majątkach należących do rezydencji w Norzyńsku najwięcej uprawiano żyta ozimego, owsa oraz hreczki. Pola zasiewano również żytem jarym, pszenicą ozimą i jarą, jęczmieniem, prosem i grochem ${ }^{23}$. W dobrach klasztoru w Niżniowie najwięcej wysiewano tatarki, żyta, pszenicy i owsa. W przypadku tej placówki widać, że jakość ziemi wpływała na strukturę uprawy. We wsiach tego klasztoru dominowały bowiem czarnoziemy, co pozwoliło na większe wysiewy pszenicy ${ }^{24}$. Natomiast struktura zasiewów w Krzeszowicach znana jest jedynie z 1745 r. Wówczas najwięcej wysiewano pszenicy i tatarki. Poza tym uprawiano pszenicę, jęczmień i groch ${ }^{25}$.

Jak widać, w placówkach paulińskich usytuowanych we wschodnich województwach Korony i na terenie Litwy uprawiano podobne rośliny. Zdecydowanie dominowała uprawa żyta, owsa oraz hreczki (gryka).

W tabeli $\mathrm{nr} 5$ zilustrowano dynamikę wysiewów w dobrach leśniańskich. W ujęciu wskaźnika dynamiki jednopodstawowego (dalej: Wdj.) zasiewy żyta prawie zawsze spadały, z wyjątkiem $1830 \mathrm{r}$. Natomiast ciągły spadek zanotowano w przypadku jęczmienia, owsa i grochu. W przypadku pszenicy w 1824 i $1839 \mathrm{r}$. zanotowano wzrost, a w pozostałych latach spadek zasiewów. Z kolei według wskaźnika dynamiki łańcuchowej (dalej: Wdł.) zanotowano zmienną sytuację.

\footnotetext{
${ }^{21}$ AJG 1658, s. 49-52; AJG 1585, s. 33.

${ }^{22}$ AJG 1532, s. 27.

${ }^{23}$ AJG 1531, s. 11-20.

${ }^{24}$ AJG 1630, s. 45-47, 52, 102-103, 107-110.

${ }^{25}$ AJG 1620, s. 48, 51.
} 
Największy wzrost zasiewów zanotowano w przypadku pszenicy w 1824 r., w wysiewach jęczmienia w 1828 r. oraz w wysiewach grochu w 1830 r. Największy spadek zasiewów zanotowano w $1815 \mathrm{r}$, jednak na ich poziom wpłynął fakt, że paulini utracili znaczną część ziemi przejętej przez zaborców, ponadto trzeba pamiętać, iż był to pierwszy rok pokoju po ośmiu latach wojen napoleońskich, które dotknęły ziemie dawnej Rzeczypospolitej.

Tabela 5. Dynamika wysiewów w dobrach klasztoru w Leśnej w latach 1747-1839

\begin{tabular}{|c|c|c|c|}
\hline Uprawa & Rok & Wdj. & Wdl. \\
\hline 1 & 2 & 3 & 4 \\
\hline \multirow{6}{*}{ żyto } & 1747 & 100,00 & - \\
\hline & 1815 & 9,33 & 9,33 \\
\hline & 1824 & 16,60 & 177,88 \\
\hline & 1828 & 13,38 & 80,60 \\
\hline & 1830 & 100,00 & 80,60 \\
\hline & 1839 & 17,76 & 132,72 \\
\hline \multirow{6}{*}{ pszenica } & 1747 & 100,00 & - \\
\hline & 1815 & 7,27 & 7,27 \\
\hline & 1824 & 109,09 & 1500,00 \\
\hline & 1828 & 87,27 & 80,00 \\
\hline & 1830 & 87,27 & 100,00 \\
\hline & 1839 & 145,45 & 166,67 \\
\hline \multirow{5}{*}{ jęczmień } & 1747 & 100,00 & - \\
\hline & 1815 & 18,63 & 18,63 \\
\hline & 1824 & 1,86 & 10,00 \\
\hline & 1828 & 7,14 & 383,33 \\
\hline & 1830 & 7,14 & 100,00 \\
\hline \multirow{5}{*}{ owies } & 1747 & 100,00 & - \\
\hline & 1815 & 33,33 & 33,33 \\
\hline & 1824 & 19,75 & 59,26 \\
\hline & 1828 & 29,63 & 150,00 \\
\hline & 1830 & 29,63 & 100,00 \\
\hline \multirow{4}{*}{ groch } & 1747 & 100,00 & - \\
\hline & 1815 & 12,24 & 12,24 \\
\hline & 1828 & 8,16 & 66,67 \\
\hline & 1830 & 18,37 & 225,00 \\
\hline \multirow{2}{*}{ proso } & 1747 & 100,00 & - \\
\hline & 1824 & 13,11 & 13,11 \\
\hline
\end{tabular}




\begin{tabular}{|c|c|c|c|}
\hline \multirow{2}{*}{$\mathbf{1}$} & $\mathbf{2}$ & $\mathbf{3}$ & $\mathbf{4}$ \\
\hline \multirow{3}{*}{ gryka } & 1815 & 100,00 & - \\
\cline { 2 - 4 } & 1824 & 100,00 & 100,00 \\
\cline { 2 - 4 } & 1828 & 50,00 & 50,00 \\
\hline
\end{tabular}

Obliczenia własne na podstawie: AJG 595, s. 147-152, 169, 173; AJG 1622, s. 277, 342-343, 353; AJG 1623, s. 54; AJG 1547, s. 117-182.

W dobrach włodawskich w latach 1745-1863 wysiewy żyta, grochu, i bobu w ujęciu Wdj. i Wdł. spadały, natomiast w odniesieniu do pszenicy, jęczmienia i owsa według obu wskaźników zanotowano wahania, a w przypadku ziemniaków wzrost. Trzeba podkreślić, że dynamika wysiewów wynikała z potrzeb folwarków, możliwości obrobienia określonego areału ziemi oraz z sytuacji społeczno-politycznej w regionie ${ }^{26}$. W przypadku rezydencji w Niżniowie w latach 1745 1754 wysiewy pszenicy według Wdj. i Wdł. wzrastały i spadały na przemian, wysiewy żyta według Wdj. ulegały zmianom, według Wdł. rosły, a owsa malały. W dobrach norzyńskich (1717-1721) dla żyta i owsa zanotowano początkowy spadek zasiewów, a następnie wzrost. W przypadku pszenicy występowała fluktuacja zasiewów. Wysiew jęczmienia spadał, a następnie bardzo wzrósł. W przypadku hreczki notowano stały wzrost wysiewów. Według Wdł. dla wszystkich roślin zaobserwowano wahania w poziomie wysiewów. W rezydencji w Horoszkach w latach 1717-1723 wysiewy żyta, jęczmienia i pszenicy w ujęciu Wdj. wzrastały, natomiast wg Wdł. ulegały zmianom. Natomiast w przypadku owsa wg Wdj. wysiewy często zmieniały się, chociaż w ujęciu Wdł. wzrastały ${ }^{27}$.

W tabeli nr 6 przedstawiono wysiewy w ujęciu całościowym. Widać, że po 1815 r. ilość wysiewanych roślin w dobrach klasztoru leśniańskiego znacząco spadła. Główną przyczyną była utrata znacznej ilości ziemi, którą przejęli zaborcy. W ujęciu Wdł. można zauważyć znaczne wahania w wysiewach, co wynikało z możliwości obrobienia konkretnej powierzchni ziemi (ilość ziarna przeznaczonego do zasiewu, zatrudnienie odpowiedniej liczby pracowników, wynikające z możliwości finansowych). Identyczna sytuacja miała miejsce w dobrach klasztoru we Włodawie. Tutaj w 1815 i 1863 r. zasiano bowiem nieco ponad 10\% wysiewów z $1745 \mathrm{r}^{28}$

Tabela 6. Dynamika wysiewów w dobrach klasztoru w Leśnej w latach 1747-1830. Ujęcie całościowe

\begin{tabular}{|c|c|c|c|}
\hline Rok & Wysiewy [korce] & Wdj. & Wdl. \\
\hline & $\mathbf{2}$ & $\mathbf{2}$ & $\mathbf{4}$ \\
\hline 1747 & 903,50 & 100,00 & - \\
\hline 1815 & 118,25 & 13,12 & 13,12 \\
\hline
\end{tabular}

\footnotetext{
${ }^{26}$ AJG 596, s. 221-223; AJG 1661, s. 231-232, 328.

${ }^{27}$ AJG 1630, s. 45-47, 52, 102-103, 107-110; AJG 1531, s. 11-20; AJG 1532, s. 27.

${ }^{28}$ AJG 596, s. 221-223; AJG 1661, s. 231-232, 328.
} 


\begin{tabular}{|c|c|c|c|}
\hline $\mathbf{1}$ & $\mathbf{2}$ & $\mathbf{3}$ & $\mathbf{4}$ \\
\hline 1824 & 138,50 & 15,33 & 117,12 \\
\hline 1828 & 130,50 & 14,44 & 94,22 \\
\hline 1830 & 130,75 & 14,47 & 100,19 \\
\hline
\end{tabular}

Obliczenia własne na podstawie: AJG 595, s. 147-152, 169, 173; AJG 1622, s. 277, 342-343, 353; AJG 1623, s. 54; AJG 1547, s. 117-182.

Z kolei w rezydencjach w Norzyńsku i Horoszkach całość wysiewów w ujęciu Wdj. i Wdł. wzrastała z niewielkimi wahnięciami w dół. Natomiast w Niżniowie zanotowano dużą fluktuację wysiewów (raz w górę, raz w dół) ${ }^{29}$. W przypadku pozostałych placówek paulińskich brak zachowanych materiałów archiwalnych, stąd nie można ocenić tendencji w zasiewach.

Jak wynika z tabeli nr 7, w Leśnej w kopach najwięcej zbierano żyta, jęczmienia, owsa i pszenicy, co odpowiadało wielkości zasiewów. Poziom plonów wahał się, co szczególnie było widoczne w XIX wieku. Wynikało to z utraty części dóbr na rzecz zaborców oraz wydzierżawianiu części ziemi. W 1854 r. zanotowano znaczny wzrost plonów, co wiązało się z rezygnacją z wydzierżawiania części majątku. Największe zbiory przypadły na 1740 r., mimo że wówczas brakowało danych dotyczących wszystkich rodzajów upraw. Najniższe plony zebrano w 1838 r., ale w następnych latach zaznaczył się ich wzrost. Najwięcej zbierano żyta i jęczmienia, a najmniej tatarki.

Tabela 7. Plony w kopach dobrach klasztoru w Leśnej 1740-1854

\begin{tabular}{|l|c|c|}
\hline \multicolumn{1}{|c|}{$\mathbf{U p r a w y}$} & Kopy $^{\mathrm{h}}$ & Odsetek [\%] \\
\hline \multicolumn{2}{|c|}{$\mathbf{2}$} & $\mathbf{3}$ \\
\hline żyto & $\mathbf{1 7 4 0}$ \\
\hline pszenica & 253,67 & 52,36 \\
\hline jęczmień & 12,00 & 2,48 \\
\hline owies & 161,92 & 33,42 \\
\hline ogółem & 56,87 & 11,74 \\
\hline & $\mathbf{4 8 4 , 4 6}$ & $\mathbf{1 0 0 , 0 0}$ \\
\hline żyto & $\mathbf{1 7 4 6}$ & 55,60 \\
\hline pszenica & 216,83 & 4,87 \\
\hline jęczmień & 19,00 & 30,41 \\
\hline owies & 118,60 & 7,06 \\
\hline tatarka & 27,53 & 2,05 \\
\hline ogółem & 8,00 & $\mathbf{9 9 , 9 9}$ \\
\hline
\end{tabular}

${ }^{\mathrm{h}}$ Kopa liczyła 60 snopów.

${ }^{29}$ AJG 1630, s. 45-47, 52, 102-103, 107-110; AJG 1531, s. 11-20; AJG 1532, s. 27. 


\begin{tabular}{|c|c|c|}
\hline 1 & 2 & 3 \\
\hline \multicolumn{3}{|c|}{1748} \\
\hline żyto & 303,90 & 72,74 \\
\hline pszenica & 13,53 & 3,24 \\
\hline jęczmień & 64,68 & 15,48 \\
\hline owies & 30,55 & 7,31 \\
\hline proso & 5,12 & 1,23 \\
\hline ogólem & 417,78 & 100,00 \\
\hline \multicolumn{3}{|c|}{1750} \\
\hline żyto & 254,17 & 88,82 \\
\hline jęczmień & 18,00 & 6,29 \\
\hline owies & 10,00 & 3,49 \\
\hline tatarka & 4,00 & 1,40 \\
\hline ogólem & 286,17 & 100,00 \\
\hline \multicolumn{3}{|c|}{1750} \\
\hline żyto & 103,00 & 55,30 \\
\hline pszenica & 28,52 & 15,31 \\
\hline jęczmień & 11,00 & 5,91 \\
\hline owies & 22,50 & 12,08 \\
\hline proso & 21,22 & 11,39 \\
\hline ogólem & 186,24 & 99,99 \\
\hline \multicolumn{3}{|c|}{1854} \\
\hline żyto & 251,53 & 59,26 \\
\hline pszenica & 30,50 & 7,19 \\
\hline jęczmień & 59,27 & 13,96 \\
\hline owies & 37,00 & 8,72 \\
\hline groch & 44,00 & 10,37 \\
\hline proso & 2,13 & 0,50 \\
\hline ogółem & 424,43 & 100,00 \\
\hline
\end{tabular}
369.

Obliczenia własne na podstawie: AJG 595, s. 170; AJG 1622, s. 277, 305-325, 342-343, 353,

We Włodawie najwięcej zbierano żyta, jęczmienia i owsa, a pszenica nie odgrywała większej roli w produkcji roślinnej. Najwięcej plonów w kopach zebrano w 1745 r., a najmniej rok później. Z danych wynika również, że najmniejsze zbiory odnotowano w 1746 r., ale w następnych latach produkcja utrzymywała się na podobnym poziomie. Analogiczna sytuacja miała miejsce w Leśnej. Tutaj w $1746 \mathrm{r}$. zanotowano spadek plonów ogółem w porównaniu z sytuacją w 1740 r. (spadek 
o 19,51\%), a najniższe plony zebrano w 1750 r. (186,24 kopy). Może to świadczyć o trudnościach gospodarczych, jednak brak informacji na ten temat w źródłach ${ }^{30}$.

Dane dotyczące struktury plonów w Niżniowie z lat 1746-1754 wykazują, że najwięcej zbierano pszenicy, tatarki, żyta, owsa i hreczki. Największe plony uzyskano w 1754 roku (2102,00 kopy), a najmniej w 1748 roku (59,50 kopy). Najwięcej zbierano pszenicy (do 379 kop), żyta(do $435 \mathrm{kop}$ ), jęczmienia (do 202 kop) i owsa (do 386 kop), a najmniej lnu (4 kopy). Z kolei w majątku rezydencji w Norzyńsku najwięcej zbierano żyta (45-172,60 kopy), hreczki (40,25-140,25 kopy) i owsa (40,25-98,17 kopy). Najniższe plony uzyskano w przypadku prosa $(8,05-10,18$ kopy) i grochu (4,07-12,03 kopy). W Horoszkach najwięcej kop zebrano w uprawie jęczmienia $(19,00-98,00)$, żyta $(13,00-77,00)$, pszenicy $(9,00-47,31)$ i owsa $(4,01$ $38,22)$. Najmniej zbierano hreczki (10,00-31,01 kopy). Trzeba również podkreślić, że w przypadku tego majątku dużą rolę odgrywała dziesięcina, która w 1723 r. pokryła całe zapotrzebowanie na produkcję roślinną. Dane z dóbr rezydencji w Krzeszowicach pochodzą tylko z 1745 r. Wówczas dominowały plony pszenicy (53 kopy), tatarki (50 kop) i jęczmienia (40 kop) ${ }^{31}$.

Część plonów zapisywano w korcach (dalej: k.), co przedstawiono w tabeli $\mathrm{nr}$ 8. Jak widać, najwięcej zbierano żyta, owsa i hreczki. Największe ilości żyta zebrano w 1720 r. (41,75 k.), a najmniejsze w 1722 r. Z kolei największe plony owsa zanotowano w 1720 r. (41 k.), a hreczki w 1718 r. (32 k.). Najwięcej zebrano żyta $(33,40 \%$ plonów), owsa $(25,47 \%)$ oraz hreczki $(21,31 \%)$, a najmniej grochu $(0,26 \%)$ i prosa $(1,37 \%)$. Łącznie plony tych trzech zbóż stanowiły $80,19 \%$ wszystkich zbiorów w latach 1717-1722.

W latach 1740-1748 widać w Leśnej stopniowy wzrost plonów w korcach. Należy podkreślić, że w 1746 i 1748 r. poziom zbiorów wzrósł o 57,70\%, co prawdopodobnie wynikało ze zwiększenia areału upraw. Najwięcej zbierano żyta, jęczmienia i owsa.

Tabela 8. Plony w korcach w dobrach klasztoru w Leśnej 1740-1748

\begin{tabular}{|l|c|c|}
\hline Uprawa & Ilość plonów [korce] & Odsetek [\%] \\
\hline \multicolumn{3}{|c|}{$\mathbf{2}$} \\
\hline żyto & $\mathbf{1 7 4 0}$ \\
\hline owies & 142,00 & $\mathbf{3}$ \\
\hline ogółem & 58,50 & 29,18 \\
\hline \multicolumn{3}{|c|}{} \\
\hline żyto & $\mathbf{2 0 0 , 5 0}$ & $\mathbf{1 0 0 , 0 0}$ \\
\hline pszenica & $\mathbf{1 7 4 6}$ & 55,66 \\
\hline jęczmień & 172,00 & 4,05 \\
\hline
\end{tabular}

${ }^{30}$ AJG 1660, s. 121-133; AJG 596, s. 55-60; AJG 601, s. 24.

${ }^{31}$ AJG 1531, s. 11-20; AJG 1630, s. 45-47, 52, 102-103, 107-110; AJG 1532, s. 27; AJG 1620, s. 48,51 . 


\begin{tabular}{|l|c|c|}
\hline \multicolumn{1}{|c|}{$\mathbf{1}$} & $\mathbf{2}$ \\
\hline owies & 45,25 & 14,64 \\
\hline tatarka & 19,50 & 6,31 \\
\hline groch & 2,25 & 0,73 \\
\hline ogółem & $\mathbf{3 0 9 , 0 0}$ & $\mathbf{1 0 0 , 0 0}$ \\
\hline \multicolumn{3}{|c|}{} \\
\hline żyto & $\mathbf{1 7 4 8}$ & 60,99 \\
\hline pszenica & 445,50 & 0,96 \\
\hline jęczmién & 7,00 & 19,27 \\
\hline owies & 140,75 & 12,49 \\
\hline tatarka & 91,25 & 2,36 \\
\hline groch & 17,25 & 1,81 \\
\hline proso & 13,25 & 2,12 \\
\hline ogółem & 15,50 & $\mathbf{1 0 0 , 0 0}$ \\
\hline
\end{tabular}

Obliczenia własne na podstawie: AJG 1622, s. 74-75, 277, 305-325, 342-343.

Z kolei we Włodawie największe plony uzyskiwano w uprawach żyta, owsa, jęczmienia i tatarki (gryki), a w XIX wieku dużą rolę odgrywała uprawa ziemniaka, którego w 1843 r. zebrano 155 korców, co stanowiło 35,67\% wszystkich plonów $^{32}$. W przypadku pozostałych placówek paulińskich brak informacji na temat ilości zebranych korców. W tabeli nr 9 zaprezentowano dynamikę plonów w dobrach leśniańskich. W ujęciu Wdj. plony w kopach w uprawie jęczmienia, owsa i tatarki były niższe od punktu wyjścia w $1740 \mathrm{r}$. Z kolei plony żyta ulegały wahaniu, a plony pszenicy były zawsze wyższe. Natomiast plony w kopach w ujęciu Wdł. dla żyta, pszenicy, jęczmienia, owsa i prosa znacznie się wahały. Z kolei zbiory tatarki (gryki) spadały. Plony w korcach w ujęciu Wdj. i Wdł. dla żyta, jęczmienia i grochu zwiększały się, pszenicy spadały, a owsa ulegały wahaniom.

Tabela 9. Dynamika plonów w dobrach klasztoru w Leśnej w latach 1740-1854

\begin{tabular}{|l|c|c|c|}
\hline Uprawa & Rok & Wdj. & Wdl. \\
\hline \multirow{4}{*}{$\mathbf{1}$} & $\mathbf{2}$ & $\mathbf{3}$ & $\mathbf{4}$ \\
\hline \multirow{4}{*}{ żyto } & \multicolumn{2}{|c|}{ plony w kopach } \\
\cline { 2 - 4 } & 1740 & 100,00 & - \\
\cline { 2 - 4 } & 1746 & 85,48 & 85,48 \\
\cline { 2 - 4 } & 1748 & 119,80 & 140,16 \\
\cline { 2 - 4 } & 1750 & 100,20 & 83,65 \\
\cline { 2 - 4 } & 1838 & 40,60 & 40,52 \\
\cline { 2 - 4 } & 1854 & 99,16 & 244,20 \\
\hline
\end{tabular}

${ }^{32}$ AJG 1660, s. 121-133; AJG 596, s. 55-60; AJG 601, s. 24. 


\begin{tabular}{|c|c|c|c|}
\hline 1 & 2 & 3 & 4 \\
\hline \multirow{5}{*}{ pszenica } & 1740 & 100,00 & - \\
\hline & 1746 & 158,33 & 158,33 \\
\hline & 1748 & 112,75 & 71,21 \\
\hline & 1838 & 237,67 & 210,79 \\
\hline & 1854 & 254,17 & 106,94 \\
\hline \multirow{6}{*}{ jęczmień } & 1740 & 100,00 & - \\
\hline & 1746 & 73,25 & 73,25 \\
\hline & 1748 & 39,94 & 54,54 \\
\hline & 1750 & 11,12 & 27,83 \\
\hline & 1838 & 6,79 & 61,11 \\
\hline & 1854 & 36,60 & 538,82 \\
\hline \multirow{6}{*}{ owies } & 1740 & 100,00 & - \\
\hline & 1746 & 48,41 & 48,41 \\
\hline & 1748 & 53,72 & 110,97 \\
\hline & 1750 & 17,58 & 32,73 \\
\hline & 1838 & 39,56 & 225,00 \\
\hline & 1854 & 65,06 & 164,44 \\
\hline \multirow{2}{*}{ tatarka } & 1746 & 100,00 & - \\
\hline & 1748 & 50,00 & 50,00 \\
\hline \multirow{3}{*}{ proso } & 1748 & 100,00 & - \\
\hline & 1750 & 414,45 & 414,45 \\
\hline & 1854 & 41,60 & 10,04 \\
\hline \multicolumn{4}{|c|}{ plony w korcach } \\
\hline \multirow{3}{*}{ żyto } & 1740 & 100,00 & - \\
\hline & 1746 & 121,13 & 121,13 \\
\hline & 1748 & 313,73 & 259,01 \\
\hline \multirow{2}{*}{ pszenica } & 1746 & 100,00 & - \\
\hline & 1748 & 56,00 & 56,00 \\
\hline \multirow{2}{*}{ jęczmień } & 1746 & 100,00 & - \\
\hline & 1740 & 244,78 & 244,78 \\
\hline \multirow{3}{*}{ owies } & 1740 & 100,00 & - \\
\hline & 1746 & 44,48 & 44,48 \\
\hline & 1748 & 155,98 & 201,66 \\
\hline \multirow{2}{*}{ tatarka } & 1746 & 100,00 & - \\
\hline & 1748 & 88,46 & 88,46 \\
\hline
\end{tabular}




\begin{tabular}{|c|c|c|c|}
\hline $\mathbf{1}$ & $\mathbf{2}$ & $\mathbf{3}$ & $\mathbf{4}$ \\
\hline \multirow{2}{*}{ groch } & 1746 & 100,00 & - \\
\cline { 2 - 4 } & 1748 & 588,89 & 588,89 \\
\hline
\end{tabular}

Obliczenia własne na podstawie: AJG 595, s. 170; AJG 1622, s. 74-75, 277, 305-325, 342-343, 353,369 .

Wydajność z jednej omłóconej kopy zbóż w latach 40. XVIII wieku była niewielka, podobnie zresztą jak we Włodawie. Przede wszystkim trzeba jednak zwrócić uwagę na znaczny spadek wydajności żyta między 1740 a 1746 r. Zauważono również wzrost plenności pszenicy w latach 1746-1748. Najwyższą urodzajność zanotowano w przypadku pszenicy, a najmniejszą prosa. W 1748 r. zaobserwowano spadek wydajności w produkcji jęczmienia i owsa, a wzrost żyta i pszenicy wzrosła.

Tabela 10. Wydajność z omłóconej 1 kopy w dobrach klasztoru w Leśnej w latach 1740-1748

\begin{tabular}{|l|c|c|c|c|}
\hline \multirow{2}{*}{ Rok } & Uprawa & Ilość plonów [kopy] & $\begin{array}{c}\text { Uzyskano } \\
\text { z omlotu [korce] }\end{array}$ & $\begin{array}{c}\text { Wydajność z 1 kopy } \\
\text { w korcach }\end{array}$ \\
\hline $\mathbf{1 7 4 0}$ & żyto & 253,50 & 142,00 & 1,79 \\
\hline \multirow{4}{*}{$\mathbf{1 7 4 6}$} & żyto & 107,00 & 170,00 & 0,63 \\
\cline { 2 - 5 } & pszenica & 19,00 & 12,75 & 1,49 \\
\cline { 2 - 5 } & jęczmień & 51,00 & 55,25 & 0,92 \\
\cline { 2 - 5 } & owies & 27,50 & 45,50 & 0,60 \\
\cline { 2 - 5 } & tatarka & 8,00 & 11,50 & 0,70 \\
\hline \multirow{4}{*}{$\mathbf{1 7 4 8}$} & żyto & 294,00 & 445,00 & 0,66 \\
\cline { 2 - 5 } & pszenica & 13,50 & 6,75 & 2,00 \\
\cline { 2 - 5 } & jęczmień & 65,00 & 140,75 & 0,46 \\
\cline { 2 - 5 } & owies & 31,00 & 91,25 & 0,34 \\
\cline { 2 - 5 } & proso & 5,00 & 15,50 & 0,32 \\
\hline
\end{tabular}

Obliczenia własne na podstawie: AJG 1622, s. 74-75, 277, 305-325, 342-343.

Wydajność z 1 kopy w dobrach włodawskich w 1745 r. kształtowała się następująco: żyto - 0,28 k., owies $-0,19$ k., tatarka (gryka) - 0,21 k.; 1746 r.: żyto - 0,66 k., jęczmień - 1,19 k. Z kolei wydajność z 1 omłóconej kopy w Horoszkach w 1720 r. wynosiła: żyto- 1,47 k., pszenica - 1,75 k., jęczmień - 6,83 k., owies - 1,41 k., hreczka $-1,70$ k. i proso - 2,46 k. Natomiast w Krzeszowicach z 1 kopy uzyskano $2 \mathrm{k}$. pszenicy, 3,75 k. jęczmienia, $4 \mathrm{k}$. tatarki i $2 \mathrm{k}$. grochu ${ }^{33}$. Jak widać, w uprawie żyta największą wydajność osiągnięto w Leśnej w 1740 r. (1,79k.), pszenicy w Horoszkach w 1720 r. i w Leśnej w 1748 r. (po 2 k.), jęczmienia w Horoszkach w 1720 r. (6,83 k.) oraz w owsa w Leśnej w 1746 r. (0,60 k.). Nieco dziwi tak duża

${ }^{33}$ AJG 1532, s. 27; AJG 1620, s. 48, 51; Szpak, Sytuacja ekonomiczna klasztoru, s. 700. 
wydajność w przypadku owsa w Horoszkach. Być może spisujący dokumenty zakonnik wliczył do plonów również dziesięciny lub zakupione ziarno i nie odnotował tego faktu.

Trzeba także podkreślić, że na ilość plonów oraz wydajność wpływało wiele czynników. Należy tutaj wymienić warunki naturalne, czyli gleby, klimat, klęski żywiołowe i działania zbrojne, które toczyły się w rejonie klasztoru czy rezydencji. Występowało wówczas zagrożenie życia i zdrowia oraz liczne grabieże dokonywane przez maszerujące armie. Na przykład wojna z lat 1812-1813 przyniosła znaczne straty klasztorowi leśniańskiemu i włodawskiemu. Utrata zwierząt, straty w sprzętach, budynkach, ornatach, albach, odzieży, naczyniach kościelnych, żywności, sztućcach i naczyniach kuchennych, zasiewach i gotówce wyniosły łącznie 9851 złp. Działania zbrojne w okresie powstania listopadowego przyniosły również zniszczenia w Leśnej ${ }^{34}$. Należy również wspomnieć o zajazdach na majątki klasztorne organizowane przez szlachtę, np. w Leśniowie, Norzyńsku i Horoszkach czy Krzeszowicach ${ }^{35}$

W tabeli nr 11 zilustrowano strukturę wydatków plonów. Zboża wyprodukowane w dobrach klasztoru w Leśnej w 1746 r. wydawano w obrębie własnych dóbr. Najwięcej wydatkowano na zasiewy i spożycie w klasztorze. Identyczna sytuacja miała miejsce w XVIII wieku w dobrach klasztoru we Włodawie (zasiewy: 1730,00 korców, 72,17\%; spożycie: 521,50 korców, 21,76\%). Kolejne wydatki to: obroki, ordynaria i propinacja. Zatem jedyna różnica to brak nakładów na propinację w Leśnej ${ }^{36}$.

Z kolei w Leśnej w 1838 r. większość zużytego zboża sprzedano (62,37\%), co zapewne wynikało z potrzeb finansowych klasztoru. Dane te mogą świadczyć o rozwoju rynku wewnętrznego w rejonie Leśnej. W połowie XVIII wieku najwięcej zbóż wydawano na zasiew (58,93\%), a najmniej na paszę dla zwierząt hodowlanych. Z kolei w 1838 r. wysiewy obejmowały zdecydowanie mniejszy odsetek wydatkowanego zboża. Może to świadczyć o wzroście wydajności produkcji, co mogło być spowodowane właściwą techniką orki, lepszym gatunkowo ziarnem lub efektywniejszym i większym nawożeniem. Natomiast w przypadku dóbr włodawskich brak informacji z XIX wieku³7.

${ }^{34}$ AJG 1548, s. 369-373.

${ }^{35}$ J. Szpak, Szlachta koronna wobec zakonu paulinów w XVIII w., w: Między barokiem a oświeceniem. Prawo i bezprawie, red. S. Achremczyk, J. Kiełbik, Olsztyn 2018, s. 173-178.

${ }^{36}$ Szpak, Sytuacja ekonomiczna klasztoru, s. 701.

${ }^{37}$ AJG 595, s. 227-229, 5-8, 26-29; AJG 1622, s. 177-178, 183, 199-200, 27, 305-3257; AJG 1547, s. 209-215; AJG 1548, s. 247-248. 
Tabela 11. Zużycie plonów w dobrach klasztoru w Leśnej w 1746 i 1838 r.

\begin{tabular}{|l|c|c|}
\hline Kategoria wydatków & Ilość wydatków [korce] & Odsetek [\%] \\
\hline \multicolumn{3}{|c|}{$\mathbf{1 7 4 6}$} \\
\hline wysiewy & 171,50 & 58,93 \\
\hline pomoc poddanym & 10,25 & 3,52 \\
\hline pasza dla zwierząt hodowlanych & 6,75 & 2,32 \\
\hline spożycie na miejscu i ordynaria & 102,50 & 35,22 \\
\hline ogółem & $\mathbf{2 9 1 , 0 0}$ & $\mathbf{9 9 , 9 9}$ \\
\hline & $\mathbf{1 8 3 8}$ & 29,67 \\
\hline wysiewy & 130,75 & 18,15 \\
\hline ordynaria czeladzi & 80,00 & 52,18 \\
\hline sprzedaż & 230,00 & $\mathbf{1 0 0 , 0 0}$ \\
\hline ogółem & $\mathbf{4 4 0 , 7 5}$ & \\
\hline
\end{tabular}

Obliczenia własne na podstawie: AJG 495, s. 227-229; AJG 595, s. 5-8, 26-29; AJG 1622, s. 177-178, 183, 199-200, 270, 305-325; AJG 1547, s. 209-215; AJG 1548, s. 247-248.

W majątkach klasztoru w Niżniowie w 1749 r. najwięcej wydano na wysiewy $(32,77 \%)$, na pomoc poddanym $(23,11 \%)$ i na paszę dla zwierząt $(12,61 \%)$. W rezydencji w Horoszkach w 1718 r. najwięcej wydawano na wysiewy $(65,04 \%)$, propinację $(8,51 \%)$ oraz paszę dla zwierząt $(6,88 \%)$. Z kolei w Norzyńsku w 1722 r. wydatki na paszę stanowiły 40\%, ordynarię dla czeladzi oraz spożycie w rezydencji po $29,63 \%$.

Jak wynika z przedstawionych danych, najwięcej ziarna wydawano na zasiew, sprzedaż, spożycie w poszczególnych placówkach, na paszę dla zwierząt hodowlanych, propinację, pomoc poddanym oraz ordynarię czeladzi. Ilość i struktura wydatków zależała od ilości plonów oraz od potrzeb w danym roku gospodarczym.

\section{Gospodarka hodowlana}

Gospodarka hodowlana pełniła rolę pomocnicza w folwarku. Przede wszystkim miała ona dostarczyć siły pociągowej oraz mięsa, skór, jaj i pierza. Dane dotyczące gospodarki hodowlanej w Leśnej pochodzą z lat 1740-1854. Z tabeli nr 12 wynika, że najwięcej zwierząt hodowano w 1753 r., a najmniej w 1742 r. (jednak dane z 1742 r. są niepełne). Brak wołów w 1817 r. wynikał albo z problemów gospodarczych po wojnie 1812-1813, albo oddano je na utrzymanie poddanym. Szczególnie dużo zwierząt pociągowych utrzymywano w 1753 r. Duży spadek pogłowia wołów w latach 1838-1839 wynikał z oddania ich poddanym, to samo dotyczyło bydła rogatego. Hodowla owiec była istotna w XVIII wieku, natomiast

i Folwarki w Leśnej, Droblinie i Klukowszczyźnie.

j W Droblinie 39 sztuk, w Klukowszczyźnie 19 sztuk, 45 sztuk w Buczembalu.

${ }^{k}$ Folwarki w Leśnej i Klukowszczyźnie.

${ }^{38}$ AJG 1660, s. 121-133; AJG 1630, s. 52, 102-103, 107-110; AJG 1532, s. 27; AJG 1531, s. 11-20. 
po 1795 r. nie miała ona znaczenia. Co prawda w latach 40. XIX wieku próbowano odbudować hodowlę, ale zaraza z 1845 r. zabiła aż 200 sztuk tych zwierząt. Chów drobiu miał zawsze charakter pomocniczy, mimo dużej liczby ptactwa. Pszczoły występowały w inwentarzach tylko w $1753 \mathrm{r}$. Trudno jednak powiedzieć, czy w późniejszych latach nie trzymano pszczół, czy może tylko nie odnotowano tego faktu w dokumentach ${ }^{39}$.

Tabela 12. Hodowla w dobrach klasztoru paulinów w Leśnej w latach 1740-1839

\begin{tabular}{|l|c|c|c|c|c|c|c|c|}
\hline Rok & Woły & Konie & $\begin{array}{c}\text { Bydlo } \\
\text { rogate }\end{array}$ & Owce & $\begin{array}{c}\text { Trzoda } \\
\text { chlewna }\end{array}$ & Drób & $\begin{array}{c}\text { Ule } \\
\text { pszczele }\end{array}$ & Razem \\
\hline 1740 & 2 & 12 & 107 & 143 & 73 & 289 & - & 626 \\
\hline 1742 & 7 & 7 & 38 & - & - & - & - & 52 \\
\hline $1753^{\mathrm{i}}$ & 34 & 22 & $103^{\mathrm{j}}$ & 63 & 63 & 402 & 5 & 692 \\
\hline $1815^{\mathrm{k}}$ & 4 & 1 & 25 & 9 & 7 & 55 & - & 101 \\
\hline 1817 & - & 4 & 23 & - & 12 & 25 & - & 54 \\
\hline 1823 & 20 & 5 & 35 & - & 14 & 108 & - & 182 \\
\hline 1838 & 18 & 10 & 43 & 19 & 9 & 285 & - & 394 \\
\hline 1839 & 4 & 8 & 21 & 18 & 15 & 146 & - & 212 \\
\hline
\end{tabular}

Obliczenia własne na podstawie: AJG 495, s. 2. 147, 169-170, 323; AJG 546, APP t. 17, s. 25; AJG 1622, s. 73-74, 79-81, 86, 90, 142-152; AJG 1623, s. 57;AJG 1547, s. 134-158.

W 1839 r. spadło pogłowie prawie wszystkich gatunków zwierząt, z wyjątkiem trzody chlewnej. Taka sytuacja wynikała z problemów gospodarczych, jakie dotykały klasztor. Wymownie o tym świadczy korespondencja ówczesnego przeora, o. Wacława Paneckiego z prowincjałem. Na początku lipca 1838 r. pisał on, że w oborze zostały jedynie trzy sztuki trzody, a drób, woły i konie były w bardzo złej kondycji, dlatego trzeba było kupić dwa nowe woły. Brakowało również sia$\mathrm{na}^{40}$. Jednak w ciągu kilku miesięcy W. Paneckiemu udało się stopniowo odbudować pogłowie zwierząt, a w 1843 r. planował zorganizować hodowlę 30 krów. Jednak już w 1845 r. pojawiła się zaraza, która zabiła 6 sztuk bydła mlecznego ${ }^{41}$.

Z kolei w dobrach włodawskich w latach 1711-1863 najwięcej hodowano drobiu, ale jego znaczenie gospodarcze było zdecydowanie mniejsze niż innych zwierząt. Najważniejszą rolę odgrywała hodowla bydła mlecznego, podobnie jak w Leśnej. Dużą rolę w folwarkach włodawskich odgrywał również chów koni

${ }^{i}$ Folwarki w Leśnej, Droblinie i Klukowszczyźnie.

${ }^{j}$ W Droblinie 39 sztuk, w Klukowszczyźnie 19 sztuk, 45 sztuk w Buczembalu.

${ }^{k}$ Folwarki w Leśnej i Klukowszczyźnie.

${ }^{39}$ AJG 595, s. 147-152, 173; AJG 495, s. 2. 147, 169-170, 323; AJG 1547, s. 134-158; AJG 1622, s. 73-74, 79-81, 86, 90, 142-152; AJG 1623, s. 57; AJG 546, APP, t. 17, s. 25.

${ }^{40}$ AJG 595, s. 41-44, 53-55, 147-152, 173, 233-234.

${ }^{41}$ AJG 595, s. 147-152, 173. 
i trzody chlewnej (konie $11,13 \%$, trzoda $8,31 \%)^{42}$. W majątkach rezydencji horoszkowskiej najwięcej było drobiu $(44,76 \%)$, trzody $(20,98 \%)$ oraz bydła mlecznego $(17,48 \%)$. Ponadto hodowano woły $(6,99 \%)$ jako siłę pociągową oraz owce $(9,79 \%)^{43}$. W Norzyńsku trzymano najwięcej sztuk drobiu $(50,58 \%)$, trzody $(17,65 \%)$ oraz bydła mlecznego $(11,76 \%)$. Tutaj obok wołów $(9.41 \%)$ hodowano również konie $(5,88 \%)$, a także owce $(4,71 \%)^{44}$. Wreszcie w Niżniowie w latach $1742-1755$ prowadzono hodowlę owiec $(33,58 \%)$, drobiu $(27,56 \%)$, bydła mlecznego $(14,41 \%)$, koni $(2,15 \%)$, wołów $(3,34 \%)$, kóz $(7,06 \%)$ oraz trzody $(11,89 \%)^{45}$. Natomiast dla rezydencji w Krzeszowie zachowały się dane jedynie z $1723 \mathrm{r}$. Wówczas fundator przekazał paulinom jedynie dwa konie oraz cztery woły, czyli siłę pociągową, która miała zapewnić możliwość prac polowych ${ }^{46}$. Natomiast nie zachowały się żadne informacje źródłowe dotyczące hodowli w folwarkach rezydencji wileńskiej.

Jak wynika z zachowanych materiałów archiwalnych, w dobrach paulińskich usytuowanych we wschodnich województwach hodowano właściwie te same gatunki zwierząt. Woły i konie wykorzystywano jako siłę pociągową w pracach polowych oraz transporcie, bydło oprócz tego dostarczało mięsa, skór oraz mleka, a trzoda i drób mięsa, skór oraz pierza. Mimo że hodowano znaczną liczbę drobiu i często stanowił on poważny odsetek hodowli, to jednak nie odgrywał on tak istotnej roli jak inne zwierzęta. Tylko w jednej placówce hodowano kozy, natomiast owce trzymano w Leśnej, Włodawie i Norzyńsku. Liczba zwierząt w poszczególnych folwarkach zależała od ilości paszy oraz od potrzeb gospodarczych, podobnie jak w majątkach klasztoru na Jasnej Górze w Częstochowie ${ }^{47}$.

\section{Narzędzia rolnicze}

W XVIII wieku w folwarkach leśniańskich orki dokonywano sochami. W inwentarzu zapisano, że w trzech gospodarstwach znajdowały się po dwa narzędzia tego rodzaju, a wśród sześciu soch dwie były z sośnikami. Ponadto korzystano z wozów kowanych (2 sztuki), wozów gołych (6 sztuk), wózka parokonnego i półkarety. Używano żaren, sierpów i siekaczy do sieczki ${ }^{48}$. W XIX wieku nadal wykorzystywano do orki sochy z sośnikami. Korzystano też z bron z żelaznymi zębami, wozów, sierpów, bryczki parokonnej krytej. Posiadano również oporządzenie do jazdy konnej ${ }^{49}$.

${ }^{42}$ AJG 1660, s. 5-6, 81-86, 93-95, 101-105, 111-115, 173-177, 211-221, 227-235; AJG 1661, s. 322-323; AJG 596, s. 55-60, 67-68, 70-81.

${ }^{43}$ AJG 1532, s. 18.

${ }^{44}$ AJG 1611, s. 5-10.

${ }^{45}$ AJG1630, s. 41-42, 45-48, 53, 59-61, 127-131.

${ }^{46}$ AJG 1620, s. 3-6.

${ }^{47}$ J. Szpak, Polska prowincja paulinów od XVII wieku do 1864 roku. Dzieje gospodarcze: klasztor na Jasnej Górze w Częstochowie, Katowice 2020, s. 354-355, 521.

${ }^{48}$ AJG 1622, s. 142-152.

${ }^{49}$ AJG 1623, s. 58-59. 


\section{Gospodarka pozarolnicza}

Sporą rolę w działalności ekonomicznej klasztoru odgrywała gospodarka pozarolnicza, czyli młynarstwo (młyny wodne), propinacja oraz produkcja cegieł ${ }^{50}$. W 1742 r. w Klukowszczyźnie browar i karczma stały puste. W 1750 r. w Malowej Górze działał browar, a 1753 r. browary i gorzelnie funkcjonowały w Leśnej, Droblinie, Klukowszczyźnie i Buczembalu ${ }^{51}$. W 1824 r. w Leśnej rozebrano jednak browar ze względu na zły stan budowli, która groziła zawaleniem. Działały też dwie karczmy, w Leśnej i Klukowszczyźnie. Propinacja była jednak wydzierżawiana przez przeorów osobom świeckim ${ }^{52}$. W 1840 r. browar w Leśnej został rozebrany i nie działał do $1847 \mathrm{r}^{53}$

W folwarkach leśniańskich istniały również dwie cegielnie. Jedną założył proboszcz, ks. Fabiański i hrabina Sedlnicka ${ }^{54}$. Wydajność cegielni była zróżnicowana, np. w 1740 r. wyprodukowano 29000 cegieł. Sto lat później wydajność wahała się od 2000 do 3000 sztuk rocznie. Cegielnia produkowała przede wszystkim na potrzeby własne, np. na budowę nowego klasztoru. W latach 30. i na początku lat 40. XIX wieku wyprodukowano 55000 sztuk cegie ${ }^{55}$. W 1832 r. na remont kościoła w Leśnej wydano 62000 cegieł $^{56}$. Część produkcji sprzedawano, np. w 1847 r. za 200 sztuk cegieł uzyskano 8 złp. (złotych polskich) ${ }^{57}$.

W dobrach włodawskich również działały młyny, ale w XVII wieku proboszczowie uzyskali prawo mlewa w zakładach należących do dziedziców włodawskich, stąd też paulini nie prowadzili dalej młynów. W latach 1739-1819 zakonnicy mieli cegielnię. W klasztorze tym w $1711 \mathrm{r}$. zatrudniono również cieślę, który pracował na potrzeby klasztoru. Jak w każdym gospodarstwie folwarcznym, tak i we Włodawie produkowano alkohol. W inwentarzach z 1711, 1745, 1747 oraz 1753 r. poświadczony jest browar. Jednak poziom produkcji był niewielki i była ona przeznaczona na spożycie własne ${ }^{58}$.

Klasztor niżniowski posiadał w Oknianach browar i gorzelnię, które produkowały podstawowy wówczas asortyment, czyli piwo i gorzałkę̨9. W Krzeszowicach z kolei działał tylko jeden zakład, cegielnia. Powstała ona w 1723 r. za zgodą ordynata Tomasza Józefa Zamoyskiego na terenie należącym do miasta Krzeszowic. Jednak w tym rejonie brakowało gliny, dlatego za zgodą ordynata przeniesiono cegielnię ${ }^{60}$. W dobrach horoszkowskich paulini wybudowali karczmę, dwie

${ }^{50}$ AJG 1547, s. 161-173, 177-182; AJG 595, s. 43-55.

${ }^{51}$ AJG 1622, s. 79, 82, 146-152, 369.

${ }^{52}$ AJG 595, s. 227-229, 41-44, 53-55, 65, 147-151, 155, 169, 173; AJG 1622, s. 207-214; AJG 1547 , s. $161-173$.

${ }^{53}$ AJG 595, s. 53-55; AJG 1547, s. 169.

${ }^{54}$ AJG 595, s. 65; AJG 1622, s. 74-75; Maraśkiewicz, Leśna Podlaska. Architektura, s. 11-12.

${ }^{55}$ AJG 595, s. 79-81.

${ }^{56}$ AJG 1546, s. 14.

${ }^{57}$ AJG 1547, s. 164-165.

${ }^{58}$ Szpak, Sytuacja ekonomiczna klasztoru, s. 706-707.

${ }^{59}$ AJG 1630, s. 45-47, 61, 132.

${ }^{60}$ AJG 1544, s. 9; AJG 1620, s. 3-6; M. Kozaczko, Poczet ordynatów Zamoyskich, Lublin 2009, s. 43-49. 
słodownie i dwa młyny. Karczma była wypuszczana w arendę ${ }^{61}$. Z kolei rezydencja w Norzyńsku posiadała trzy młyny, browar, cztery winnice, folusz do barwienia tkanin i szynk. W dobrach norzyńskich produkowano gorzałkę oraz piwo jasne i pszenne oraz być może wino ${ }^{62}$.

Przemysł dworski, jak widać, odgrywał ważną rolę w majątkach klasztornych. Przerabiano produkcję roślinną, zapewniając podstawowe artykuły spożywcze. Jednak młyny, browary i gorzelnie, sprzedające swoje proukty, również były źródłem dochodów finansowych.

\section{Finanse klasztoru i kościoła w Leśnej}

Liczebność konwentu leśniańskiego była zróżnicowana, na co wpływała kondycja ekonomiczna klasztoru. W 1731 r. pracowało tam 9 zakonników, w 1752 i 1770 r. aż 11, w 1790 r. - 8, w 1795 r. - 4, a w 1827 r. tylko 3. Zatem liczba paulinów pracujących w Leśnej wahała się od 3 do 11 osób, a średnia wynosiła 6 zakonników ${ }^{63}$. Trzeba również pamiętać o zatrudnionej w klasztorze służbie. W 1753 w Klukowszczyźnie pracowały 3 osoby (gospodarz z żoną i parobkiem), a w folwarku Buczembal $5^{64}$. W 1838 r. służba liczyła 15 osób, z kolei w 1846 r. - 20. Średnio paulini leśniańscy zatrudniali ok. 10 osób, a zatem w klasztorze żyło łącznie ok. 16 osób. Wszystkim należało zapewnić ubiór, wyżywienie i mieszkanie ${ }^{65}$.

Dane dotyczące struktury przychodów finansowych zachowały się dla lat 17291731, 1827-1828, 1837-1839, 1840-1841, 1846-1849, 1855-1856. Łącznie w tym okresie uzyskano 92 544,29 złp., czyli średnio w roku 9254,03 złp, najwięcej z czynszów za prawo propinacji, czynszów z dzierżaw folwarków, wyderkafów oraz operacji bankowych. Za odsetki i za listy zastawne wpłynęło łącznie 14 326,05 złp., czyli 15,48\% całej ustalonej kwoty (1855-1856). Na uwagę zasługuje również odszkodowanie, jakie paulinom leśniańskim wypłaciły władze wojskowe w lipcu $1730 \mathrm{r}$. za nieprawnie pobrane świadczenia. Pewną rolę odgrywały również: zwrot długów, opłaty za posługi religijne oraz pomoc finansowa władz zakonu w latach 1840-1844 r. Natomiast niewiele uzyskano ze sprzedaży produkcji rolniczej, hodowlanej i z przemysłu dworskiego (1846-1849 sprzedaż cegieł). Należy także podkreślić, że w latach 1842-1844 paulini leśniańscy pozyskali znaczną kwotę (1000 złp.) z działalności wydawniczej. Jednak aż 18,09\% ustalonej kwoty to sumy o nieznanym pochodzeniu.

Podsumowując zagadnienie przychodów klasztoru w Leśnej, trzeba zauważyć, że ich źródła były liczniejsze w XIX wieku. Przychody można podzielić na stałe i niestałe. Do pierwszej kategorii należały czynsze z dzierżaw dóbr ziemskich i propinacji oraz odsetki od sum umieszczonych w bankach. Do przycho-

${ }^{61}$ AJG 1532, s. 155, 159-162; AJG 1610, s.3-7.

${ }^{62}$ AJG 1611, s. 4-10, 67.

${ }^{63}$ AJG 528, s. 2-3, 6-8, 36-37; AJG 595, s. 297; AJG 539, APP, t. 11a, s. 87-88; AJG 540, APP, t. 11b, s. 124-125; AJG 543, APP, t. 13, s. 205-207; AJG 544, APP, t. 15, s. 7-9; AJG 545, APP, t, s. 51-53; AJG 547, APP, t. 18, s. 286; AJG 807, APP, t. 21, s. 118-120, 392-393, 431-433, 469-47; Szafraniec, Decus-Podlachiae Ozdoba ..., s. 25.

${ }^{64}$ AJG 1622, s. 146-152.

${ }^{65}$ AJG 595, s. 147-151; AJG 807, APP t. 21, s. 119; AJG 1624, s. 109. 
dów niestałych zaliczano sumy wyderkafowe ${ }^{66}$, prowizje od pożyczek udzielonych przez klasztor, odszkodowanie za straty spowodowane przez wojsko oraz odszkodowania sądowe, z działalności gospodarczej, z posług religijnych, pomoc finansową władz zakonu, sumy z listów zastawnych, działalność wydawniczą i darowizny. Na szczególna uwagę zasługują sumy wyderkafowe, które miały przynosić znaczne przychody, ale z reguły były niewypłacane lub wypłacano je z dużym opóźnieniem. Pomoc władz zakonu pojawiała się wówczas, gdy w Leśnej budowano nowy klasztor. Konkludując, należy zauważyć, że w XVIII wieku gospodarka klasztorna była nastawiona na samowystarczalność, co było charakterystyczne dla gospodarki folwarczno-pańszczyźnianej. Natomiast w XIX wieku paulini w Leśnej zaczęli aktywniej działać w różnych dziedzinach ówczesnej gospodarki. Byli zapewne zmuszeni do tego, ponieważ dobra ziemskie w znacznej części zostały utracone po III rozbiorze. Z drugiej strony pojawiły się również możliwości działalności rynkowej ${ }^{67}$.

Tabela 13. Struktura przychodów w klasztorze paulinów w Leśnej w latach 1729-1856

\begin{tabular}{|l|c|c|}
\hline \multicolumn{1}{|c|}{$\mathbf{1}$} & Kwota [zl-gr] & Odsetek [\%] \\
\hline niezidentyfikowane & $\mathbf{2}$ & 18,09 \\
\hline dzierżawa prawa propinacji & $16739,17^{12}$ & 13,72 \\
\hline $\begin{array}{l}\text { czynsze od dzierżawców } \\
\text { dóbr }\end{array}$ & 12700,00 & 13,49 \\
\hline odsetki wyderkafowe & 12481,25 & 11,13 \\
\hline $\begin{array}{l}\text { odsetki z depozytów } \\
\text { bankowych }\end{array}$ & 10296,25 & 8,22 \\
\hline spłata listów zastawnych & 7606,05 & 7,26 \\
\hline $\begin{array}{l}\text { wyrównanie strat przez } \\
\text { wojsko }\end{array}$ & 6720,00 & 6,81 \\
\hline zwrot długów & 6300,09 & 6,75 \\
\hline opłaty za posługi religijne & 6250,00 & 5,95 \\
\hline pomoc władz zakonu & 5510,00 & 5,07 \\
\hline prowizja od pożyczki & 4696,14 & 1,25 \\
\hline działalność wydawnicza & 1155,00 & 1,08 \\
\hline
\end{tabular}

${ }^{66}$ Klasztor i kościół w Leśnej otrzymały łącznie zapisy na 449 379,00 złp., a odsetki wynosiły 26 882,16 złp. Zob. AJG 1624, s. 91; AJG 1623, s. 17, 48-53; AJG 1545, s. 67; AJG 1548, s. 1-7, 9; AJG 1547, s. 177-182.

${ }^{67}$ J. Szpak, Sytuacja finansowa klasztoru paulinów w Leśnej Podlaskiej, „Magazyn Numizmatyczny", (2019) nr 45, s. 77-78. 


\begin{tabular}{|l|c|c|}
\hline \multicolumn{1}{|c|}{$\mathbf{1}$} & $\mathbf{2}$ & $\mathbf{3}$ \\
\hline działalność gospodarcza & 935,00 & 1,01 \\
\hline darowizny & 153,24 & 0,17 \\
\hline ogółem & $\mathbf{9 2 5 4 4 , 2 9}$ & $\mathbf{1 0 0 , 0 0}$ \\
\hline
\end{tabular}

Obliczenia własne na podstawie: AJG 594, s. 1-10; AJG 595, s. 1-9, 17-19, 26-29, 41-55, 65, 99-102, 147-155, 169, 173, 183-184, 187-191, 243, 227-229, 233-234, 243, 335; AJG 807, APP t. 21, s. 360; AJG 1622, s. 176-178, 183-201, 207-214; AJG 1624, s. 59, 67, 75, 107-109; AJG 1547, s. 177-182, 209-215, 217; AJG 1548, s. 109, 11-113, 151-158, 247-248, 357, 361-363, 365-368.

Z kolei klasztor włodawski najwięcej uzyskał z darowizn (46,62\% ustalonej kwoty), wyderkafów (12,66\%), sprzedaży ziemi (8,89\%), wynajmu lokali $(5,98 \%)$ oraz z wsparcia władz zakonu (5,62\%). Odsetki bankowe stanowiły tylko 4,74\% kwoty, co świadczy o niewielkim znaczeniu działalności finansowej we Włodawie. Najmniej uzyskano z ofiar od wiernych oraz za odszkodowanie za pożar budynków klasztornych $(0,1 \%)^{68}$. W rezydencji w Niżniowie w 1786 r. struktura przychodów wyglądała następująco: czynsze 513,19 złp., czyli 59,19\% oraz wyderkafy 354,25 złp., co stanowiło 40,81\% całej zebranej kwoty ${ }^{69}$. W Krzeszowicach w 1746 r. najwięcej uzyskano ze sprzedaży produkcji rolnej i zwierzęcej (319 złp., 50,39\%), a następnie z tytułu darowizn od szlachty (296 złp., 46,76\%) oraz pomoc ze strony władz prowincji (18 złp., 2,84\% $)^{70}$. W rezydencji w Horoszkach w latach 1717-1723 struktura dochodów kształtowała się następująco: pomoc zakonu 3369,15 złp.; sprzedaż produkcji rolnej - 2530,27 złp.; dzierżawa karczmy 2180,25 złp.; czynsze od poddanych - 787,25 złp.; sprzedaż zwierząt - 622 złp.; zwrot udzielonych pożyczek - 572,09 złp.; przychody niezidentyfikowane - 200 złp; darowizna fundatora - 174 złp.; sprzedaż grzybów - 46,12 złp. oraz dziesięciny - 14 złp. Jak więc widać, najważniejsza była pomoc finansowa udzielona przez prowincję, która stanowiła 32,10\% wszystkich przychodów w badanym okresie. Najmniejsze przychody zanotowano z dziesięcin, ale miały one charakter wytyczny. Ta niewielka kwota była zapewne uzyskana z tytułu opłaty za zaległe dziesięciny. Na uwagę zasługuje fakt uzyskania znacznej kwoty ze sprzedaży szeroko rozumianej produkcji rolnej, kategoria ta stanowiła $24,10 \%$ wszystkich przychodów. Duże znaczenie miały także przychody z tytułu dzierżawy karczmy było to $20,77 \%$ całej sumy uzyskanej w latach $1717-1723$. Pozostałe źródła przychodów nie odgrywały tak poważnej roli. Do przychodów stałych należy zaliczyć jedynie kwoty z dzierżawy karczmy. Pozostałe źródła miały charakter niestały, pojawiały się tylko czasem, a ich wysokość była zróżnicowana ${ }^{71}$. W rezy-

${ }^{68}$ AJG 1661, s. 39, 321-322; AJG 596, s. 27-47, 2-6; AJG 601, s. 25; AJG 1660, s. 221-223, 236-237.

${ }^{69}$ AJG 1631, s. 17, 49; Archiwum Narodowe w Krakowie, Teki Schneidra 1149, s. 360-361, 363.

${ }^{70}$ AJG 1620, s. 54.

${ }^{71}$ AJG 974, s. 2-10; 1610, s.1-2. 
dencji w Norzyńsku w latach 1716-1723 uzyskano 7062,28 złp., w tym: z czynszów i danin od poddanych 1930,27 złp. (27,33\%), z dziesięciny 134 złp. (1,90\%), z dzierżawy browaru i młyna 1828 złp. $(25,88 \%)$, ze sprzedaży produkcji rolnej (miód i zboża) 365,24 złp. (5,17\%), z opłat w zamian za pańszczyznę 125 złp. (1,77\%) oraz z odszkodowań 156,01 złp. (2,21\%). Pozostałych źródeł przychodów nie zidentyfikowano $(2523,06 \text { złp., } 35,74 \%)^{72}$. W przypadku rezydencji wileńskiej dane dotyczące struktury przychodów są szczątkowe i pochodzą jedynie z Dobrianowa, z 1732 r. Z czynszów uzyskano wówczas 505,10 złp. (56,43\%), ze sprzedaży zboża 360 zł (40,22\%), a z karczmy 30 zł (3,35\%) ${ }^{73}$.

Na podstawie zachowanych materiałów archiwalnych można stwierdzić, że w klasztorach i rezydencjach paulińskich działających we wschodniej części Rzeczpospolitej dominowały przychody z dzierżaw, odsetek bankowych, wyderkafów, pomocy od władz prowincji, wynajmu lokali, darowizn, sprzedaży produkcji rolnej i zwierzęcej. W XIX wieku w majątkach klasztorów leśniańskiego i włodawskiego dużą rolę odgrywały odsetki bankowe oraz wynajem lokali.

\section{Struktura wydatków}

Dane dotyczące wydatków pochodzą z lat: 1745-1750, 1835-1838, 1839-VII 1842, VII 1842-VII 1846, VII 1846-VII 1848 i 1854-1856. Łącznie zatem informacje dotyczą ok. 20 lat. Wydatki wynosiły wówczas 116415,25 złp., czyli średnio rocznie 5821,01 złp., jednak średnia ma charakter jedynie orientacyjny. Najwięcej wydatkowano na budowę nowego kościoła i klasztoru w latach 1729-1758 i 1835-1846. Prowadzono także remonty w świątyni parafialnej w Leśnej, szpitala parafialnego oraz budynków gospodarczych. Jednak część środków przeznaczonych na budowę klasztoru w XIX wieku uzyskano od władz zakonu, np. w okresie VII 1842-VII 1843 z kasy prowincjała otrzymano 13 303,24 złp., a od przeora włodawskiego o. Edwarda Janowskiego 500 złp. Duża część wydatków to podatki i różne opłaty związane z obowiązkami nałożonymi przez państwo. Były to: ofiara 10 grosza, subsidium charitativum, szarawark, podatek szosowy, zakup Dziennika Gubernialnego, podatek za wójta i za proboszcza, podatek od broni palnej, liwerunek dworski, składka ogniowa z kościoła, probostwa i klasztoru oraz podymne dawne. Dużą rolę w wydatkach odgrywały pensje dla czeladzi, utrzymanie i leczenie zakonników oraz spłata długów. Tutaj należy wspomnieć, że zalegano z zapłatą pensji czeladzi, np. w latach 1838-1842 zadłużenie wyniosło 799 złp. Natomiast w latach 40. XIX wieku przeor leśniański musiał również zwrócić 1000 złp. klasztorowi na Skałce w Krakowie oraz 500 złp. zakrystii jasnogórskiej. Na uwagę zasługuje fakt, że przeor o. Izydor Ordon na wezwanie władz powstania listopadowego za kwotę 383 złp. wystawił kawalerzystę w pełnym oporządzeniu i z koniem.

${ }^{72}$ AJG 973, s. 1-10.

73 AJG 1585, s. 9, 13, 37, 49-52, 57, 65; E. Hawelski, Cathalogus patrum ac fratrum Ordinis S. Pauli Primi Eremitae, „Studia Claromontana”, 30 (2012) s. 440-441. 
W dniu 14 XII 1830 r. dotarł on do Siedlec i zameldował się w nowo formowanym oddziale krakusów, którym dowodził Antoni Kuszell ${ }^{74}$.

Podsumowując, największe nakłady ponoszono na prace budowlane i remontowe. Duży odsetek wydatków stanowiły także składki na potrzeby zakonu, podatki i płace dla służby. Ponadto pieniądze wydatkowano na spłatę długów, pensje dla duchownego unickiego, pensje dla wójta, utrzymanie zakonników, koszty sądowe, różnego rodzaju zakupy na potrzeby klasztoru (papier, woły), utrzymanie kościoła, zakup świec i żywności, koszty transportu oraz leczenia i usługi rzemieślnicze. Paulini udzielali również pożyczek. Trzeba też pamiętać, że znaczna część opłat nie została zidentyfikowana. W XIX wieku wśród wydatków pojawiły się zakupy potrzebnych produktów, np. papieru, żywności, napojów itp. Potwierdza to tezę o ukształtowaniu się zalążka rynku wewnętrznego w rejonie Leśnej ${ }^{75}$.

\section{Tabela 14. Struktura wydatków klasztoru paulinów w Leśnej w latach 1745-1856}

\begin{tabular}{|l|c|c|}
\hline \multicolumn{1}{|c|}{$\mathbf{1}$} & Kwota [zlp./gr] & Odsetek [\%] \\
\hline Rodzaj wydatków & $\mathbf{2}$ & $\mathbf{4}$ \\
\hline wydatki budowlane' $^{1}$ & 56309,02 & 17,76 \\
\hline niezidentyfikowane & 20739,03 & 9,66 \\
\hline podatki & 11284,16 & 6,70 \\
\hline pensje dla służby & 7826,02 & 6,41 \\
\hline $\begin{array}{l}\text { utrzymanie i leczenie } \\
\text { zakonników }\end{array}$ & 7427,23 & 4,01 \\
\hline spłata długów & 4684,14 & 2,65 \\
\hline utrzymanie świątyni & 3100,00 & 2,57 \\
\hline na potrzeby zakonu & 3000,00 & 0,69 \\
\hline zakup napojów i żywności & 811,17 & 0,43 \\
\hline $\begin{array}{l}\text { pensja dla duchownego } \\
\text { unickiego }\end{array}$ & 500,00 & 0,33 \\
\hline $\begin{array}{l}\text { wystawienie żołnierza } \\
\text { w 1831 r. }\end{array}$ & 383,00 & 0,24 \\
\hline zakup wołów & 280,00 & . \\
\hline
\end{tabular}

${ }^{1} 26$ 812,16 zł przekazano na mocy decyzji cara ze skarbu państwa rosyjskiego. Było to odszkodowanie za majątki przejęte przez Rosję po 1795 r. W tej kategorii zapisano wydatki na budowę nowego klasztoru oraz na remonty.

${ }^{74}$ AJG 1548, s. 373; T. Strzeżek, Kawaleria Królestwa Polskiego w powstaniu listopadowym, Olsztyn 2010, s. 201.

${ }^{75}$ Szpak, Sytuacja finansowa klasztoru, s. 82-83. 


\begin{tabular}{|l|c|c|}
\hline \multicolumn{1}{|c|}{$\mathbf{1}$} & $\mathbf{2}$ & $\mathbf{3}$ \\
\hline pensja dla zastępcy wójta & 200,00 & 0,17 \\
\hline koszty sądowe & 126,20 & 0,11 \\
\hline usługi rzemieślnicze & 44,03 & 0,04 \\
\hline inne $^{\mathrm{m}}$ & 26,05 & 0,02 \\
\hline ogółem $^{\prime}$ & $\mathbf{1 1 6 7 9 8 , 2 5}$ & $\mathbf{1 0 0 , 0 0}$ \\
\hline
\end{tabular}

Obliczenia własne na podstawie: AJG 520, s. 43, 49; AJG 564, s. 41-46, 69; AJG 594, s. 1-2; AJG 595, s. 3-9, 17-19, 26-29, 41-55, 65, 79-81, 99-102, 147-155, 169, 173, 183-184, 187-191, 195-196, 227-229, 243, 227-229, 233-236, 243, 353; AJG 1546, s. 3-5, 7, 9, 57-58, 73-75, 92, 95-97, 123-124, 127-128, 143-145, 153-155, 159, 165, 177, 199, 203-204, 207, 209; AJG 1547, s. 161-173, 209-215, 217; AJG 1548, s. 109, 111-133, 245, 247-248, 253-255, 357, 359, 361-363, 365-368; AJG 1622, s. 123, 176-178, 183-201, 207-214; AJG 1624, s. 75, 78-79, 93, 101, 103; AJG 807, APP, t. 21 , s. 360; J. Maraśkiewicz, Leśna Podlaska. Architektura ..., s. 12-13; K. Szafraniec, Decus-Podlachiae. Ozdoba ..., s. 25, s. 16; J. Zbudniewek, Katalog domów i rezydencji ..., s. 208-209. J. Zbudniewek, Paulini wczoraj i dzisiaj..., s. 231-233.

Z kolei w klasztorze włodawskim najwięcej wydano na prace budowlane i remontowe (52 382,06 złp., 60,24\% ustalonej kwoty), utrzymanie klasztoru i kościoła (11 528,20 złp., 13,25\%), podatki (7203,27 złp., 8,28\%), pensje dla czeladzi (5053,22 złp., 5,81\%), usługi rzemieślnicze (2072,26 złp., 2,38\%) oraz spłatę długów (5422,00 złp., 6,24\%). Kwota niezidentyfikowana wynosiła 5422,00 złp., co stanowiło $6,24 \%$ całości. Wśród innych nakładów pieniężnych znalazły się: wydatki na gospodarstwo folwarczne (706,27 złp., 0,81\%), podróże (379,02 złp., $0,44 \%)$, opłata za dzierżawę gruntów (20,00 złp., 0,23\%), utrzymanie rabina we Włodawie (100,00 złp., 0,11\%) oraz wypłata odsetek od wyderkafu (75,00 złp., $0,09 \%)^{76}$. W Horoszkach w latach $1717-1725$ najwięcej wydatkowano na wsparcie finansowe klasztoru jasnogórskiego (1700 złp., 24,39\%) oraz na wpłatę na depozyt (1613 złp., 23,14\%). Ponadto paulini wydawali pieniądze na zakup żywności i napojów, na zakup zwierząt hodowlanych, na pensje dla czeladzi, na podróże, na inwestycje w gospodarstwo $(10,22$ złp., $0,16 \%)$, na jałmużnę i prezent dla fundatora. Jednak znaczna kwota - 2848,07 złp. - została wydana bez zapisania celu, stanowiła ona $40,86 \%$ całej zebranej sumy ${ }^{77}$.

Placówki paulińskie przeznaczały środki finansowe na różne cele, w zależności od potrzeb, konieczności oraz możliwości finansowych. Konwenty w Leśnej i Włodawie najwięcej wydatkowały na prace budowlane i remontowe, podatki oraz pensje dla czeladzi. Natomiast w Horoszkach dominowało wsparcie finansowe dla klasztoru jasnogórskiego. Jednak struktura wydatków we wszystkich placówkach była bardzo podobna. Przede wszystkim środki finansowe miały zapewnić odpowiedni stan budowli kościelnych i klasztornych.

${ }^{\mathrm{m}} \mathrm{W}$ tym transport 6,20 złp., zakup leków 10,15 złp., zakup papieru 8,00 złp.

${ }^{76}$ AJG 1661, s. 21, 47, 231-232, 321; AJG 1660, s. 221-223; AJG 601, s. 25-26; AJG 507, s. 3958; AJG 596, s. 27-47, 67-68, 70-81, 205.

${ }^{77}$ AJG 974, s. 81-108; AJG 1610, s.1-2. 


\section{Bilans finansowy}

Zachowany materiał archiwalny pozwolił na określenie bilansu finansowego w latach 1729-1859. Trzeba jednak podkreślić, że po 1795 r. sytuacja ekonomiczna klasztoru w Leśnej była trudna, co było spowodowane m.in. utratą części dóbr ziemskich na rzecz Rosji (Konstantynów, Klawań i Żebranie) oraz stratami, jakie poniósł klasztor w wyniku działań zbrojnych w latach 1812-1813 $(9851 \mathrm{zl})^{78}$.

Z tabeli nr 15 wynika, że sytuacja finansowa klasztoru w Leśnej była niestabilna. Okresy prosperity były przeplatane okresami kryzysów. Należy jednak podkreślić, że w pierwszej połowie XVIII wieku zaznaczył się spadek sum uzyskiwanych przez klasztor. W latach 1842-1846 sytuacja finansowa zdecydowanie się poprawiła, ale już w latach 50. XIX wieku przychody znacznie zmalały. Na 8 okresów rozliczeniowych, w 7 przypadkach klasztor osiągnął zysk. Natomiast u schyłku lat 50. XIX wieku zaznaczył się deficyt finansowy. Średnio w ciągu 21 lat uzyskano 203 332,16 złp., wydano 148 854,10 złp., a końcowy bilans był dodatni i wynosił 54 478,06 złp. Natomiast średni zysk roczny wynosił 2874,00 złp. Trzeba jednak pamiętać, że wyliczenia średniej mają charakter orientacyjny, a sytuacja finansowa zależała od wielu czynników, m.in. od tego czy w regionie toczyły się działania zbrojne, czy warunki naturalne były sprzyjające gospodarce rolnej i hodowlanej, czy panowały w zarazy. W niektórych okresach sytuacja paulinów leśniańskich była bardzo trudna. Przykładem może być 1838 r., kiedy to nowy przeor o. W. Panecki borykał się z dużymi problemami ekonomicznymi. Sytuację finansową musiał ratować przez wydzierżawienie propinacji oraz sprzedaż siana za $130 \mathrm{złp}$. Klasztor był jednak zadłużony na znaczną kwotę 2570,07 złp. ${ }^{79}$

${ }^{78}$ AJG 1545, s. 15-18, 67-70; AJG 1548, s. 369-372.

${ }^{79}$ AJG 564, s. 41-46, 69; AJG 595, s. 5-8, 17-19, 26-29, 41-44, 53-55, 147, 152-154; AJG 1546, s. $57-58,73-75,92,95-97,123-124,127-128,143-145,153-155,159,165,177$; AJG 1548, s. 109 , 111-133, 245, 247-248, 253-255; AJG 1547, s. 209-215, 217; Zbudniewek, Katalog domów i rezydencji, s. 208-209; Zbudniewek, Paulini wczoraj i dzisiaj, s. 231-233; Szpak, Sytuacja finansowa klasztoru, s. 85. 
Tabela 15. Bilans finansowy klasztoru paulinów w Leśnej w latach 1729-1859. Dane ogólne

\begin{tabular}{|l|c|c|c|}
\hline $\begin{array}{l}\text { Okres } \\
\text { rozliczeniowy }\end{array}$ & $\begin{array}{c}\text { Przychody } \\
\text { [zlp./gr] }\end{array}$ & Wydatki [zlp./gr] & $\begin{array}{c}\text { Bilans finansowy } \\
\text { [zlp./gr] }\end{array}$ \\
\hline $1727-I X 1729$ & 10413,21 & 1436,01 & $+8977,20$ \\
\hline $1729-1731$ & 40783,00 & 28372,17 & $+12410,13$ \\
\hline $1733-1736$ & 36292,01 & 32507,08 & $+3784,23$ \\
\hline $1736-1739$ & 25756,11 & 15521,20 & $+10234,21$ \\
\hline $1745-1748$ & 20896,06 & 10677,20 & $+10228,16$ \\
\hline $1748-1750$ & 17047,14 & 11849,18 & $+5197,26$ \\
\hline $1842-1846$ & 33389,22 & 29407,26 & $+3981,26$ \\
\hline VI 1857-VI 1859 & 18754,01 & 19081,20 & $-326,11$ \\
\hline średnia & $\mathbf{2 0 3} \mathbf{3 3 2 , 1 6}$ & $\mathbf{1 4 8} \mathbf{8 5 4 , 1 0}$ & $+\mathbf{5 4} \mathbf{4 7 8 , 0 6}$ \\
\hline
\end{tabular}

Obliczenia własne na podstawie: AJG 594, s. 1-3; AJG 595, s. 1-4, 5-9, 17-19, 26-29, 41-55, 65, 99-102, 147-155, 169, 173, 183-184, 187-191, 243, 227-229, 233-234, 243, 335; AJG 807, APP t. 21, s. 360; AJG 1622, s. 176-178, 183-201, 207-214; AJG 1624, s. 59, 67, 69, 72-73, 75, 78-79, 85, 93, 101, 103, 107-109, 318; AJG 1547, s. 161-173, 177-182, 209-215, 217; AJG 1548, s. 109, $11-$ 113, 151-158, 247-248, 357, 361-363, 365-368.

Warto również przyjrzeć się bilansowi finansowemu klasztoru włodawskiego, który również znajdował się na obszarze województwa brzesko-litewskiego. We Włodawie w latach 1722-1863 uzyskiwano z reguły dodatni bilans finansowy. Tylko w 4 okresach rozliczeniowych zanotowano deficyt (1739-1742, 1742-1745, 1745-1748, 1845-1847), natomiast w 6 okresach osiągnięto zysk. Jednak jego wysokość była niewielka, wahał się on od 307 złp. (1722-1725 r.), do 6697 złp. (1817 r.). Natomiast średni zysk roczny wynosił zaledwie 25 złp. ${ }^{80}$. Widać zatem, że przeorowie klasztoru w Leśnej radzili sobie znacznie lepiej w dziedzinie gospodarczej niż przełożeni z Włodawy.

W klasztorze niżniowskim w latach 1740-1780 osiągano zawsze dodatni bilans finansowy. Uzyskiwano duże nadwyżki gotówki, które wahały się od 6490 złp. do 15508 złp. Łącznie w badanym okresie uzyskano 202 724,13 złp., a wydano 148 249,03 złp., zatem bilans dodatni wynosił 54 475,10 złp. ${ }^{81}$ Trudno powiedzieć, jak wyglądał bilans finansowy rezydencji krzeszowickiej, ponieważ jedyne dane pochodzą z 1748 r. Wówczas uzyskano 1430,19 złp., a wydano 2807 zł. Zatem zanotowano niedobór w kwocie aż 1376,11 złp. Jednak trudno powiedzieć, czy dla rezydencji w Krzeszowicach była to sytuacja typowa, czy incydentalna $^{82}$. Sytuacja finansowa w rezydencji w Norzyńsku była zróżnicowana, po cztery razy osiągano zysk i notowano straty finansowe. Łącznie w latach 1717-

${ }^{80}$ AJG 1661, s. 13, 29, 31, 39, 45, 47, 231-232, 321; AJG 1660, s. 173-177, 221-223, 236-237; AJG 601, s. 25-26, 229, 231, 269; AJG 507, s. 46-47, 49, 59-66; AJG 596, s. 27-47, 299.

${ }^{81}$ AJG 540, APP, t. 11b, s. 22, 231, 342, 585; AJG 541, APP, t. 12, s. 22; AJG 1630, s. 55; AJG 1631, s. $13,15,17,49,51,53$.

${ }^{82}$ AJG 1620, s. 57. 
1723 uzyskano 7062,28 złp., a wydano 6901,04 złp. bilans był dodatni, ale uzyskana kwota niewielka, zaledwie $81,24 \mathrm{zlp}^{83}$. Z kolei w Horoszkach w latach 1717-1725 bilans finansowy był siedem razy dodatni, a dwa razy ujemny. Łącznie uzyskano 10 513,14 złp., a wydatkowano 8350,16 złp., zatem zysk wynosił $2162,8 \mathrm{zlp}^{84}$

Podsumowując, można stwierdzić, że w początkowym okresie funkcjonowania klasztoru w Leśnej przychody i wydatki były niewielkie. Wpływy w latach 1731-1748 spadały, aby następnie wzrosnąć. Podobna sytuacja miała miejsce w przypadku wydatków, z tą tylko różnicą, że w ostatnim okresie wydatki wzrosły, to zaś spowodowało niewielki deficyt finansowy. Zyski były zróżnicowane, ale w XVIII wieku były na dobrym poziomie, natomiast w XIX wieku zyski były niewielkie. W pozostałych placówkach paulińskich działających na wschodnich terenach sytuacja finansowa ulegała wahaniom, ale z przewagą dodatnich bilansów. Uwaga ta dotyczy jednak tylko XVIII wieku.

\section{Zakończenie}

Klasztor paulinów w Leśnej powstał z fundacji średnioszlacheckiej na pograniczu polsko-litewskim. Od początku placówka otrzymała bogate uposażenie w dobrach ziemskich. Jednak paulini utracili część swoich zapisów w sporach z potomkami księcia F.M. Szujskiego. O wiele bardziej bolesne dla klasztoru były jednak straty spowodowane przez rozbiory, kiedy to Rosjanie przejęli większość dóbr. W latach 1795-1864, czyli do końca funkcjonowania klasztoru, paulini gospodarowali w czterech wsiach. Zatem sytuacja ekonomiczna zależała przede wszystkim od sytuacji politycznej panującej na ziemiach polskich.

Klasztor leśniański otrzymał tak duże uposażenie, że zajmował on pod tym względem drugie miejsce w polskiej prowincji paulinów, po klasztorze jasnogórskim. Gospodarstwo w Leśnej było prowadzone w podobny sposób jak w innych dobrach, czy to kościelnych, królewskich czy szlacheckich. Uprawiano te same rodzaje roślin i hodowano te same gatunki zwierząt. W XVIII wieku folwark klasztorny miał służyć przede wszystkim zaspokojeniu potrzeb osób żyjących i pracujących w klasztorze i gospodarstwie folwarcznym. Dopiero w XIX wieku pojawił się rynek wewnętrzny, który umożliwił sprzedaż części produkcji.

Trzeba podkreślić, że na pograniczu Korony i Litwy, w latach 40. XVIII wieku nastąpił kryzys w gospodarce roślinnej. Dotknął on zarówno klasztor leśniański, jak i włodawski. Trudno jednak powiedzieć, co było jego powodem. Być może spowodowany był przez trudne warunki naturalne, np. upały, deszcze lub szarańcze.

W dobrach klasztoru w Leśnej najważniejszą rolę w gospodarce roślinnej odgrywały cztery podstawowe zboża: pszenica, żyto, jęczmień i owies. Inne rośliny odgrywały tylko rolę pomocniczą. Podobna sytuacja występowała w pozostałych placówkach paulińskich działających na wschodzie Rzeczpospolitej. Trzeba jednak podkreślić, że w Niżniowie, Horoszkach i Norzyńsku uprawiano grykę, która odrywała tam ważną rolę, w przeciwieństwie do majątków leśniańskich czy wło-

\footnotetext{
${ }^{83}$ AJG 973, s. 1-10, 90-119.

${ }^{84}$ AJG 1610, s.1-2; AJG 974, s. 2-10, 81-108.
} 
dawskich. We Włodawie w XIX wieku w przeciwieństwie do Leśnej wprowadzono uprawę ziemniaków, która odgrywała istotną rolę gospodarczą. Pozostałe placówki, których gospodarkę omawiano, działały w XVIII wieku, kiedy ziemniaków nie uprawiano.

Wydajność z 1 omłóconej kopy zbóż w latach 40. XVIII wieku w dobrach klasztorów w Leśnej i Włodawie była niewielka i spadała, co wynikało z jakiegoś kryzysu w gospodarce. Trzeba zauważyć, że w Horoszkach i Krzeszowicach wydajność z 1 omłóconej kopy w latach 20 . XVIII wieku była wyższa., ale zależała ona od wielu czynników, na które człowiek nie miał wpływu (anomalie pogodowe, zarazy itp.).

W XVIII wieku uzyskane plony w największej części wydatkowano na zasiewy i spożycie w klasztorze. W XIX wieku przeorzy leśniańscy zaczęli sprzedawać część plonów na rynku wewnętrznym. Natomiast w przypadku dóbr włodawskich brak informacji z XIX wieku. W gospodarce hodowlanej w obu klasztorach dominował chów bydła mlecznego, wołów i trzody chlewnej.

W omawianych klasztorach i rezydencjach funkcjonowały młyny (z wyjątkiem Włodawy), browary, gorzelnie i cegielnie. Ich produkcja była wykorzystywana przede wszystkim na potrzeby własne. Jednak propinacja w dobrach leśniańskich i włodawskich nie odgrywała większej roli, a w XIX wieku była oddawana w dzierżawę w Leśnej, a we Włodawie zupełnie nie realizowano tego uprawnienia. Natomiast duże znaczenie miała ona w rezydencji norzyńskiej.

Źródła przychodów, jak i rozchodów były podobne we wszystkich omawianych placówkach. Jednak sytuacja finansowa w Leśnej przedstawiała się nieco lepiej niż we Włodawie, najlepsza zaś była w placówce w Niżniowie. Reasumując, należy podkreślić, że klasztor w Leśnej utrzymywał się samodzielnie. Jedynie w latach 30. XIX wieku władze zakonu wsparły finansowo ówczesnego przeora o. W. Paneckiego.

\section{REFERENCES / BIBLIOGRAFIA}

\section{Źródła rękopiśmienne}

Archiwum Zakonu Paulinów na Jasnej Górze w Częstochowie (AJG) sygn. 451, św. Barbara. Inwentarz 1801-1809.

sygn. 487, Omłot zboża w roku 1804 in actum klasztoru św. Barbary.

sygn. 490 (Św. Barbara. Inwentarz 1773-1792).

sygn. 491, Percepta conseminationum crescentiarum Monasterii Novitiatus ad S. Barbaram ab Anno 1774.

sygn. 495, Percepta monasteris S. Barbara Anno 1807.

sygn. III-515, K. Płócienniczak: Dzieje konwentu paulinów we Lwowie (1750-1786). Praca dyplomowa, mps.

sygn. 528, Liber Actorum Provonciae Gallicaiae Occidentalis.

sygn. 558 (Łęczeszyce 1661-1819).

sygn. 595, Leśna Podlaska.

sygn. 596, Włodawa. 
sygn. 757, Regestra percepta Monasteri Novitatus ad Sanctam Barbaram.

sygn. 926, Fundusze i kapitały klasztoru świetej Barbary.

sygn. 952, Święta Barbara 1703-1745.

sygn. 1007, Inwentarz dóbr Glosków 1726-1733.

sygn. 1009, Ostromęczyn. sygn. 1010, Konwent Warszawa.

sygn. 1012, Warszawa. Inwentarz 1711.

sygn. 1507, Św. Barbara 1726-1864.

sygn. 1511, Konwent ś. Barabry 1610-1796.

sygn. 1529, Konwent Brzozów 1726-1728.

sygn. 1530, Konwent Stara Wieś.

sygn. 1531, Norzyńsk.

sygn. 1532, Rezydencja Horoszki 1712-1728.

sygn. 1538, Akta XX Paulinów. Klasztoru Konopnicy.

sygn. 1539, Konwent Konopnica 1551-1856.

sygn. 1544, Rezydencja Krzeszów 1722-1742.

sygn. 1545, Konwent Leśna 1829-1837.

sygn. 1546, Fabryka Leśna 1728-1855.

sygn. 1547, Leśna.

sygn. 1548, Konwent Leśna 1726-1929.

sygn. 1549, Opisy kościołów w Żarkach i Leśniowie 1825-1836.

sygn. 1550, Konwent Leśniów 1822-1824.

sygn. 1554, Konwent Łęczeszyce 1639-1815.

sygn. 1557, Rezydencja Niżniów.

sygn. 1565, Konwent Topolno 1683-1803.

sygn. 1567, Włodawa.

sygn. 1568, Warszawa.

sygn. 1585, Wilno.

sygn. 1603, Brzozów 1735-1753.

sygn. 1610, Rezydencja Horoszki 1725-1729.

sygn. 1614, Konopnica 1702-1851.

sygn. 1615, Konopnica 1687-1860.

sygn. 1620, Xsiążka jasnogórska. Forteca.

sygn. 1622, Leśna 1728-1856.

sygn. 1623, Leśna 1688-1815.

sygn. 1624, Leśna 1727-1863.

sygn. 1625, Leśniów 1707-1862.

sygn. 1627, Łęczeszyce 1703-1802.

sygn. 1629, Łęczeszyce 1641-1827.

sygn. 1630, Niżniów.

sygn. 1639, Topolno. Inwentarz 1711.

sygn. 1640, Conventus Varszaviensis 1721.

sygn. 1641, Prowincja Topolno 1687-1806.

sygn. 1642, Warszawa 1703-1755.

sygn. 1644, Warszawa 1674-1818.

sygn. 1645, Warszawa.

sygn. 1658, Wilno.

sygn. 1661, Włodawa 1700-1861.

sygn. 1671, Jasna Góra. Posiadłości w Częstochowie 1532-1848.

sygn. 2174, Miraculorum B. V. Claromontanae... Secundus Tomus. 
Actorum Provinciae Poloniae (APP)

AJG, 537; APP, t. 7; AJG, 546; APP, t. 17; AJG, 539; APP, t. 11a; AJG, 540; APP, t. 11b; AJG, 543; APP, t. 13; AJG, 544; APP, t. 15; AJG, 545; APP, t. 16; AJG, 547; APP, t. 18; AJG, 807; APP, t. 21.

Archiwum Narodowe w Krakowie (ANKr)

sygn. 1514, Teki Schneidra (TSch.).

Archiwum Archidiecezjalne w Częstochowie (AACz)

sygn. 19, Księgi Konsystorskie (KK).

Archiwum Główne Akt Dawnych w Warszawie (AGAD)

sygn. 5883, 5971, Komisja Województwa Mazowieckiego-Rząd Gubernialny warszawski (KWM-RGM).

Archiwum Państwowe w Bydgoszczy (APByd)

sygn. 1, 2, 9, 12, Klasztor w Topolnie (KT).

Centralnyj Derżawnyj Istorycznyj Archiw Ukraijny, m. Lwiw (CDIAUL)

Fond 453. Opys 1. Spr. 1551.

\section{Źródla drukowane}

Księga 1 obejmujaca okres od założenia zakonu do 1663. Autor: o. Andrzej Eggerer OSPPE, w: Roczniki zakonu św. Pawła Pierwszego Pustelnika, t. 1, red. L. Chałupka, Częstochowa-Jasna Góra 2008.

Księga 2 obejmująca lata od 1663 do 1727. Autor: o. Mikołaj Benger OSPE, w: Roczniki zakonu św. Pawła Pierwszego Pustelnika, t. 1, red. L. Chałupka, Częstochowa-Jasna Góra 2008.

Księga 3. Z uzupetnieniami obejmujące lata od 1727 do 1786. Autor: o. Marcin Streska OSPEE, w: Roczniki zakonu św. Pawła Pierwszego Pustelnika, t. 1, red. L. Chałupka, Częstochowa-Jasna Góra 2008.

\section{Opracowania}

Cichor Dariusz, Dzieje kościoła i klasztoru paulinów we Włodawie 1698-1864, „Studia Claromontana", 13 (1993) s. 365-447.

Demczyszak Grzegorz, Kościót Ducha Świętego w Warszawie w świetle jego inwentarzy z lat 1676-1819, „Studia Claromontana”, 28 (2010) s. 85-152.

Dunin-Wąsowicz Anna, Pomiary gruntu w Koronie w XVI-XVIII wieku, Warszawa 1994.

Dziurka Henryk, Krzeszów, w: Monasticon Cisterciense Poloniae, t. 2: Katalog męskich klasztorów cysterskich na ziemiach polskich w dawnej Rzeczypospolitej, red. A.M. Wyrwa, Jerzy Strzelczyk, Krzysztof Kaczmarek, Poznań 1999.

Grüger Heinrich, Heinrichau. Zisterzienserabtei, „Jahrbuch der Schlesischen FriedrichWilhelms-Universität zu Breslau”, t. 23, red. J.J. Menzel, Würzburg/Main 1982.

Grüger Heinrich, Himmelwitz. Zisterzienserabtei, w: „Jahrbuch der Schlesischen Friedrich-Wilhelms-Universität zu Breslau”, t. 22, red. J.J.Menzel, Würzburg/Main 1981.

Grüger Heinrich, Leuebes. Zisterzienserabtei, w: „Jahrbuch der Schlesischen FriedrichWilhelms-Universität zu Breslau”, t. 22, red. J.J. Menzel, Würzburg/Main 1981. 
Grüger Heinrich, Rauden. Zisterzienserabtei, w: „Jahrbuch der Schlesischen FriedrichWilhelms-Universität zu Breslau”, t. 22, red. J.J. Menzel, Würzburg/Main 1981

Grüger Heinrich, Trebnitz. Zisterzienserabtei, w: „Jahrbuch der Schlesischen FriedrichWilhelms-Universität zu Breslau”, t. 23, red. J.J. Menzel, Würzburg/Main 1982.

Hawelski Eustachy, Cathalogus patrum ac fratrum Ordinis S. Pauli Primi Eremitae, „Studia Claromontana", 30 (2012) s. 385-504.

Katalog zabytków w Polsce, t. 10: Województwo warszawskie, red. I. Galicka. H., Sygietyńska, z. 5: Powiat grójecki, oprac. I. Galicka. H., Sygietyńska, Warszawa 1971, s. 39-42.

Kęder Wojciech, Jasna Góra wobec przemian politycznych $w$ Rzeczypospolitej $w$ latach 1661-1813. „Studia Claromontana”, 13 (1993) s. 5-206.

Kościelak Sławomir, Majątek ruchomy i nieruchomy klasztoru brygidek w Gdańsku u progu kasat oraz jego losy po kasacie w 1835 r. Wstęne ustalenia, w: Klasztor w gospodarce średniowiecznej i nowożytnej, red. M. Derwich, Wrocław 2013, s. 597-609.

Kozaczko Marian, Poczet ordynatów Zamoyskich, Lublin 2009.

Maraśkiewicz Janusz, Leśna Podlaska. Architektura kościoła, Biała Podlaska 1983.

Muszyńska Jadwiga, Gospodarka dworska $w$ dobrach biskupów krakowskich $w$ połowie XVII wieku, Kielce 2012.

Muszyńska Jadwiga, Gospodarka dworska w dobrach biskupstwa krakowskiego. Produkcja zbożowa w kluczu iłżeckim w połowie XVII wieku, w: Folwark-wieś-latyfundium. Gospodarstwo wiejskie w Rzeczypospolitej w XVI-XVIII wieku, red. J. Muszyńska, S. Kazusek, J. Pielas, Kielce 2009 s. 197-210.

Osiadacz Agnieszka, Rodzina Boglewskich na tle epoki XIV-XVII wieku, „Studia Claromontana", 29 (2011) s. 273-354.

Rosowski Witalij, Sytuacja gospodarcza klasztoru bernardynów w Janowie na Podolu u progu kasat oraz losy jego majatku po kasacie w 1832 r., w: Klasztor w gospodarce średniowiecznej i nowożytnej, red. M. Derwich, Wrocław 2013, s. 643-662.

Rusińska-Giertych Halina, Dochody klasztorów wynikajace z działalności typograficznej na przykładzie drukarni franciszkanów we Lwowie (1770-1776), w: Klasztor w gospodarce średniowiecznej i nowożytnej, red. M. Derwich, Wrocław 2013, s. 553-571.

Słownik wiedzy o Grójeckiem, red. Z. Szeląg, z. 11, Grójec 2002.

Strzeżek Tomasz, Kawaleria Królestwa Polskiego w powstaniu listopadowym, Olsztyn 2010.

Szafraniec Kazimierz, Decus-Podlachiae. Ozdoba Podlasia. Sanktuarium Matki Boskiej Leśniańskiej w trzechsetlecie istnienia (1683-1983), „Collectanea Teologica”, 51 (1981) nr 3, s. 5-39.

Szafraniec Sykstus, Konwent paulinów jasnogórskich 1382-1864, Rzym 1966.

Szpak Jacek, Ciężary wojskowe z dóbr starostwa brzeźnickiego w latach 1651-1793, $\mathrm{w}$ : Pecunia nervus belli. Z dziejów dyplomacji i stosunków międzynarodowych $w$ XVI -XVIII wieku, red. M. Markiewicz, R. Skowron, F. Wolański, Katowice2016 s. $207-$ 225.

Szpak Jacek, Dzieje klasztoru i parafii w Leśniowie, cz. 3: Parafia i sanktuarium Matki Bożej w Leśniowie, poddani klasztoru i parafi,, „Studia Claromontana”, 22 (2004) s. 405-636.

Szpak Jacek, Finanse starostwa kłobuckiego 1659-1789, „Magazyn Numizmatyczny”, (2014) nr 40, s. 38-48.

Szpak Jacek, Klasztor paulinów w Leśnej 1726-1864. Początki, struktura organizacyjna, życie codzienne, podstawy ekonomiczne, „Roczniki Bialskopodlaski”, 24 (2016) s. $67-88$. 
Szpak Jacek, Polska prowincja paulinów od XVII wieku do 1864 roku. Dzieje gospodarcze: klasztor na Jasnej Górze w Częstochowie, Katowice 2020.

Szpak Jacek, Sytuacja ekonomiczna klasztoru paulinów we Włodawie w latach 16981864, „Studia Claromontana”, 33 (2017/2018) s. 685-709.

Szpak Jacek, Sytuacja finansowa klasztoru paulinów w Leśnej Podlaskiej, „Magazyn Numizmatyczny", (2019) nr 45, s. 70-88.

Szpak Jacek, Szlachta koronna wobec zakonu paulinów w XVIII w., w: Między barokiem a oświeceniem. Prawo i bezprawie, red. S. Achremczyk, J. Kiełbik, Olsztyn 2018, s. 171-187.

Szpak Jacek, Gospodarka feudalna $w$ dobrach klasztoru paulinów w Leśniowie w XVIII i XIX wieku. Wybrane problemy, „Zeszyty Myszkowskie”, (2017) nr 4, s. 9-28.

Szylar Anna, ,, Sprawa o tym, jak benedyktynki gospodarstwo prowadzity...”. Organizacja i funkcjonowanie gospodarki opactwa benedyktynek w Sandomierzu w XVII i XVIII w., w: Klasztor w gospodarce średniowiecznej i nowożytnej, red. M. Derwich, Wrocław 2013, s. 447-459.

Święch Hermina, Źródła utrzymania klasztoru bernardynek przy kościele pw. św. Agnieszki na Stradomiu w Krakowie oraz stan ich dochodów u progu kasaty klasztoru w 1788 r. i po przeniesieniu konwentu do klasztoru bernardynek przy kościele pw. św. Józefa, w: Klasztor w gospodarce średniowiecznej i nowożytnej, red. M. Derwich, Wrocław 2013, s. 575-595.

Tomoń Stanisław, Fundacja paulińskiego klasztoru i kościoła pw. śś. Barbary i Andrzeja AP. w Częstochowie w pierwszej połowie wieku XVII, „Studia Claromontana”, 23 (2005) s. 183-272.

Trajdos Tadeusz M., Dobra i dochody klasztorne augustianów w Brześciu Litewskim w świetle archiwaliów konwentualnych (do końca XVII w.), w: Klasztor w gospodarce średniowiecznej i nowożytnej, red. M. Derwich, Wrocław 2013, s. 385-411.

Urzędnicy województw kijowskiego i czernihowskiego XV-XVIII wieku. Spisy, oprac. E. Janas, W. Kłaczewski, Kórnik 2002.

Urzędnicy województwa sandomierskiego XVI-XVIII wieku. Spisy, oprac. K. Chłapowski, A. Falniowska-Grabowska, red. A. Gąsiorowski, Kórnik 1993.

Zaborski Zygmunt, Parafia Wiewiec. Zarys dziejów, Częstochowa 1999.

Zaborski Zygmunt, Rezydencja paulinów w Wiewcu, „Studia Claromontana”, 6 (1985) s. 160-193.

Zbudniewek Janusz, Katalog domów i rezydencji polskiej prowincji paulinów, „Nasza Przeszłość" 31 (1969) s. 181-228.

Zbudniewek Janusz, Paulini wczoraj i dzisiaj, ,Studia Claromontana”, 25 (2007) s. 5-288.

Zbudniewek Janusz, Wkład paulinów starowiejskich w kulturę ziemi przemyskiej, „Studia Claromontana", 16 (1996) s. 345-352.

Ziółek Ewa M., Między tronem a ołtarzem. Kościót i państwo w Księstwie Warszawskim, Lublin 2012.

Złotkowski Dariusz, Udział zakonu ojców paulinów w życiu społeczno-politycznym Rzeczypospolitej w XVIII w., Częstochowa 1994.

Zmuda Remigiusz, Kasata klasztorów paulińskich na terenie Królestwa Polskiego w 1819 roku, „Studia Claromontana”, 25 (2007) s. 353-428. 


\title{
THE ECONOMIC SITUATION OF THE PAULINE MONASTERY IN LEŚNA (COMPARED TO THE ECONOMY OF OTHER PAULINE INSTITUTIONS OPERATING IN THE EASTERN PROVINCES OF THE POLISH-LITHUANIAN COMMONWEALTH)
}

\begin{abstract}
One of the most important institutions of the Polish Pauline Province in the 18th and 19th centuries was the monastery in Leśna in Podlasie (Podlachia). It was founded in 1726 by the village owner, Władysław Jan Michałowski. After the Third Partition in 1795, Leśna became part of Western Galicia, from 1809 it was part of the Duchy of Warsaw, and from 1815 to 1918 part of the Kingdom of Poland under the rule of Russian Tsars. The monastery was dissolved in 1864.
\end{abstract}

The monastery received a very large endowment. Until 1795 it owned 16 villages, but as a result of the Third Partition, the Pauline Fathers lost most of their property to the Russian treasury. Until the end of its existence, it owned only 4 villages. The acreage of the monastic land in the 18th century amounted to 4907 morgens, and after 1795 it was only 842.50 morgen $(82.83 \%$ less than before). Such a large endowment meant that the monastery in Leśna was financially the best secured convent in the Polish Pauline Province, second only to Jasna Góra.

The Paulines in Leśna sowed the greatest quantities of rye, wheat, barley, oats, and they also grew Tartary buckwheat, peas, millet, buckwheat, and flax. The level of crop production was heavily influenced by military operations that took place in the area of the monastery. At that time, there occurred threats to life and health, as well as numerous lootings carried out by marching armies, e.g., over the years 1812 to 1813 and 1831. Most of the crops were expended on sowing and consumption in the monastery, while in the 19th century part of the harvest was sold on the local market. The 19th century also seems to have witnessed an improvement in the farming culture, resulting in increased productivity. The monastic estates bred oxen and horses as beasts of burden, as well as dairy cattle, sheep, pigs, poultry, and bees. Animal husbandry was primarily intended for satisfying their own needs.

Non-agricultural economy, namely milling industry, propination (exercising local alcohol monopoly), and brick production played an important role in the economic operations of the monastery. On the basis of the preserved, incomplete archival materials, it has been established that the biggest income was obtained from lease rents, interest on special contracts for the purchase of profits from lease rents, as well as from bank deposits, and the repayment of mortgage bonds. The most substantial amounts were spent on construction and renovation works, taxes, salaries for servants and on the upkeep of monks. The financial situation of the monastery was unstable, but the monastery in Leśna supported itself without any external help, with a single exception being an assistance of the provincial authorities which happened only once, in the 1930s. Keywords: Pauline fathers; order of monks; Leśniów; Włodawa; monastic economy; Catholic church 